\title{
O REGIME SENHORIAL NA FRONTEIRA DO NORDESTE PORTUGUÊS. ALTO DOURO E RIBA CÔA (SÉCULOS XI-XIII)
}

\author{
José Augusto de Sotto Mayor Pizarro \\ Universidad de Oporto
}

RESUMEN: Este estudio pretende analizar el espacio de las regiones de Trás-os-Montes y la Beira Alta - separadas por el valle del Duero -, en sus áreas fronterizas orientales con las coronas de León/Castilla, bajo la perspectiva de la implantación del régimen señorial. A lo largo de una cronologia que se extiende desde la aparición del Condado Portucalense, a final del siglo XI, hasta la última definición fronteriza, a final del siglo XIII, se trazan las trayectorias de los linajes nobles más poderosos implantados allí, a fin de entender las diferentes formas de señorialización utilizadas, a la par que los esfuerzos de la corona para obstaculizar ese proceso. En principio, se analiza la implantación del régimen señorial en cada una de las dos regiones por separado, para considerarlas después globalmente, tanto geográfica como cronologicamente, a través del ejercicio de gobierno de los diferentes territorios por los referidos linajes, entendiendo que este fue uno de los vebículos mas importantes para la expansión del mencionado régimen.

Palabras clave: Nordeste de Portugal, León-Castilla, Frontera, Régimen Señorial, Nobleza, Linajes, Poder Regio.

ABSTRACT: In this study it is intended to analyse the space of the regions of Tras-os-Montes and of Beira Alta - separated by the valley of the River Douro - in areas of their eastern frontiers with León-Castile in the perspective of the implementation of the seigneurial system. Throughout a chronology that extends from the appearance of the County of Portucale (Oporto) at the end of the 11th century till the final definition of Portugal's frontiers in the 13th century, it follows the course of the most powerful noble lineages established there in order to understand the different forms of seigneurialisation utilized, along with the efforts of the crown to impede that process. First, the implantation of the seigneurial regime in each of those regions is analysed separately; then they are viewed globally in both geographical and chronological terms through the exercise of the government of the various lands by the noble 
bouses referred to, which, it is argued, was one of the most important vebicles for the expansion of that regime.

KEY WORDS: $\quad$ Northeast of Portugal, León-Castile, Frontier, Seigneurial regime, Nobility, Lineages, Royal Power.

\section{INTRODUÇÃO}

Falar sobre a senhorialização do espaço em epígrafe levanta, por um lado, uma série de problemas e pressupõe, por outro, a abordagem de realidades bastante diferentes, quer em termos geográficos, quer em termos históricos.

Em boa verdade, e quanto ao segundo aspecto, dever-se-ia antes falar de espaços: um primeiro, que corresponde à área fronteiriça delimitada pelo rio Douro, e que compreende os actuais concelhos de Miranda do Douro, de Mogadouro, de Freixo de Espada-à-Cinta e de Torre de Moncorvo; e um outro, confinando a norte com aquele rio, e que dele se vai depois afastando em busca da nascente do rio Côa, seu afluente, enquadrado entre a sua bacia e a fronteira com Espanha, e que abrange a área dos actuais concelhos de Vila Nova de Foz Côa, de Meda, de Figueira de Castelo Rodrigo, de Pinhel, de Almeida e de Sabugal.

Espaços integrantes da vasta rede hidrográfica do Douro superior, mas bem diferentes desde os seus limites setentrionais e meridional: ali, o terreno desenvolve-se em relevos mais agrestes, prenunciando as escarpas que se lançam abruptamente sobre o Douro, encaixado em funduras de vertigem, fazendo dessa linha de rocha e de água uma fronteira praticamente intransponível; para sul desse limite, o terreno vai-se suavizando gradualmente, até encontrarmos um relevo mais dócil, que a pouco e pouco, para nascente, vai anunciando as planuras sem horizonte da Meseta.

Mas é no plano histórico que as diferenças mais se acentuam. Com efeito, para abordarmos a senhorialização de toda esta área, somos desde logo confrontados com as profundas diferenças cronológicas e de conjuntura política que caracterizam o processo evolutivo da sua integração no território português, o qual decorre entre o início do século XII e os finais do século XIII.

Diferenças geográficas, primeiro, diferenças cronológicas e políticas, depois, e, ainda, diferentes formas de senhorialização. Questões e problemas que, finalmente, mais se adensam, tratando-se de uma região para a qual as fontes documentais não abundam, e são quantitativa ou qualitativamente desequilibradas consoante a cronologia ou a área específica que se pretende estudar.

Tendo em conta todas estas características e assimetrias, seguirei uma metodologia de análise que procurará respeitar essas mesmas diferenças, ou seja, estudarei separadamente o processo de senhorialização de cada uma das duas áreas acima referidas, até ao momento em que se conclui a sua total integração no território nacional, isto é, por ocasião da assinatura do Tratado de Alcanices, em 1297. Como é evidente, esta abordagem temática só ficará completa com 
uma análise da evolução da senhorialização deste território desde o início do século XIV até aos alvores do século XVI. Espero que, com a brevidade possível, a revista Hispania possa acolher essa segunda parte deste trabalho.

\section{Repovoamento E SenhorializaÇÃo do Douro Superior. A ACÇão DOS SENHORES DE BRAGANÇA}

Quando, presumivelmente em 1096, o conde D. Henrique chegou a Portugal e recebeu o governo do condado, ainda neste se não integrava todo o território situado para lá de Chaves até Bragança, e desde aqui, para sul, até ao Douro; como também o não integrava a área que ia desde o Távora até ao Côa, na margem esquerda daquele rio.

A sua integração, e tal como o afirmam alguns autores ${ }^{1}$, ficou a dever-se inteiramente a razões de ordem política, e pela mão de uma linhagem - os senhores de Bragança, ou melhor, para utilizar a expressão dos antigos livros de linhagens medievais, os Bragançãos.

Esta afirmação, efectivamente corroborada pela pouca documentação dos séculos XI e XII relativa a toda esta área, implica a necessidade de acompanhar a história da linhagem, de tal forma esta se confunde com a história daquele território. Tarefa de certo modo facilitada, uma vez que a sua importância levou vários autores a debruçarem-se sobre a sua trajectória, quer no quadro da História política, pelas razões que acabei de referir, quer no da História social, tendo em conta a inserção dos senhores de Bragança no grupo das famílias que representaram o topo da hierarquia nobiliárquica portuguesa durante os séculos XI, XII e XIII ${ }^{2}$.

Do prestígio e antiguidade dos Bragançãos, de resto, faziam eco os textos linhagísticos medievais portugueses, nomeadamente o mais antigo deles, o Livro Velho de Linhagens, composto em finais do século XIII, numa altura, portanto, em que a linhagem já se havia extinto:

${ }_{1}$ Sobre toda esta zona fronteiriça, especialmente a situada a norte do Douro, e muito pela escassez das fontes que a contemplam, não abundam as referências bibliográficas. Utilizarei apenas, por isso, os dois autores que deixaram os textos mais esclarecedores sobre a matéria: AZEVEDo, Luís Gonzaga de: História de Portugal, vol.V, Lisboa, Edições «Bíblion», pp.135-142, e Fernandes, A. de Almeida: Território e Política Portugalenses (Sécs. VI-XII), Porto, 1972, pp.229-254.

2 Fernandes, A. de Almeida: Território (...), pp.236-254; MATtoso, José: Ricos-Homens, Infanções e Cavaleiros. A nobreza medieval portuguesa nos Séculos XI e XII, Lisboa, Guimarães Editores, 1982, pp. 65-68 e 72, e Identificação de um País. Ensaio sobre as origens de Portugal. 1096-1325. Volume I, Oposição, Lisboa, Editorial Estampa, 1995, pp.185-187; Gomes, Paulo Dordio: «O Povoamento Medieval em Trás-os-Montes e no Alto-Douro. Primeiras impressões e hipóteses de trabalho», in Arqueologia Medieval, n. ${ }^{\circ}$ (1993), pp.172-175, e PizArro, José Augusto de Sotto Mayor: Linhagens Medievais Portuguesas. Genealogias e Estratégias (1279-1325), vol.I, Porto, Centro de Estudos de Genealogia, Heráldica e História da Família, Universidade Moderna (Porto), 1999, pp. 227-252. 
«Agora, amigos, se vos plaze vos contaremos os linhagens dos bons homens filhos d'algo do reino de Portugal dos que devem a armar e criar e que andaram a la guerra a filhar o reino de Portugal. E eles, meos amigos, foram partidos em cinco partes. A primeira parte foi el Uffo Belfager, donde vem directamente os Sousãos. A segunda parte, dom Alam [...] donde vieram os linhagens dos Bragançãos [...] A terceira geraçom foram os da Maia [...]. A quarta geraçom foram os de Baião [...]. A quinta geraçom [...] os que ora chamam de Riba de Douro»³.

A linhagem dos Bragançãos ocupava, portanto, um honroso segundo lugar na hierarquia das linhagens que ajudaram a conquistar o reino de Portugal. Este posicionamento - logo a seguir aos venerandos Sousãos, a mais antiga e prestigiada de todas as linhagens medievais portuguesas, e antes dos senhores da Maia, para cuja exaltação terá sido elaborado o próprio nobiliário- chamou-me especialmente a atenção, uma vez que será muito difícil de admitir que a ordenação daquelas cinco linhagens tivesse sido feita de uma forma aleatória, facto que procurei interpretar num trabalho recente ${ }^{4}$, e que aqui tentarei resumir em breves linhas.

Quase todas as linhagens, sobretudo as mais antigas, têm em torno das suas origens uma auréola de lenda ou de mito. No caso que aqui nos importa, a mesma fonte refere que aquele $\mathrm{D}$. Alão era «clerigo filho d'algo e filhou [raptou\} a filha d'el rei de Armenia quando foi em oração a Santiago, e foi sa hospeda em Sam Salvador de Crasto de Avelãas [...], e fege nela dous filhos donde vieram os linhagens dos Bragançãos».

Mesmo admitindo a veracidade deste episódios, não me pareceu que a ligação ilegítima referida, ainda que com uma personagem régia, fosse em si mesma justificativa do destaque dado à linhagem. No entanto, essa ligação ao sangue real não foi um caso isolado, uma vez que teve continuidade imediata através dos matrimónios de Fernão Mendes I e do seu neto homónimo, respectivamente com uma filha e uma neta de Afonso VI de Leão e Castela, o que ganhou Toled ${ }^{6}$. Deverá residir nesta dupla aliança com o sangue de uma figura

3 Portugaliae Monumenta Historica. Nova Série, Volume I, Livro Velho de Linhagens e Livro de Linhagens do Deão (ed. de Joseph Piel e de José Mattoso), Lisboa, Academia das Ciências de Lisboa, 1980, pp. 23-24 ( $L V$ e $L D$ ).

${ }_{4}^{4}$ PiZARro, José Augusto de Sotto Mayor: Linhagens (...), vol.I, pp. 225-226.

5 Benayan Carmona, Narciso: «Una princesa armenia en Compostela en el siglo XI: su genealogía», in Estudios Genealógicos, Heráldicos y Nobiliarios en honor de Vicente de Cardenas y Vicent con motivo del XXV aniversario de la Revista Hidalguía, tomo I, Madrid, 1978, pp.131-153.

${ }^{6}$ Livro de Linhagens do Deão (LD12A2). Refiro o Livro de Linhagens do Deão e o seu título XII, relativo aos de Bragança, uma vez que é muito provável que o seu autor tenha tido acesso à parte perdida do Livro Velho de Linhagens que tratava dos Bragançãos, Baiões e Riba Douro ( $L V$, «Introdução», p. 14). Naquela fonte, o protagonista do rapto é o filho de D. Alão, D. Mendo Alão, pai de D. Fernão Mendes I. Quanto a D. Mendo Alão, e segundo uma hipótese expressa há alguns anos, suponho que por FERNANDES de Almeida, seria identificável com Mem Corvo, o indivíduo responsável pelo repovoamento das terras a que daria o seu nome, agregado ao de uma velha torre -do Corvo- também por ele 
verdadeiramente mítica, como a do Imperador $\mathrm{Afonso} \mathrm{VI}^{7}$, o prestígio que a linhagem ainda detinha no final do século XIII ${ }^{8}$.

Com efeito, o referido casamento com uma filha ilegítima de Afonso VI, cujo nome se desconhece, colocava D. Fernão Mendes de Bragança I em pé de igualdade com o conde D. Henrique, e mesmo com o conde D. Raimundo. Vejamos então o que se sabe sobre tão proeminente personagem.

A primeira notícia conhecida, datada de Setembro de 1072, refere D. Fernão Mendes I como governador do território de Chaves $^{9}$ - princeps ipsius terre Ferrandus Menendiz - ou seja, pouco depois de Afonso VI recuperar a coroa de Leão e de lhe agregar a coroa de Castela, após a morte de Sancho II, que ainda em Agosto desse mesmo ano surgia à frente de ambas as coroas ${ }^{10}$. Almeida Fernandes supõe, creio que com verosimilhança, que a substituição de Fernão Mendes à frente de Chaves no referido documento de Agosto, poderia significar o seu afastamento da tenência quando Sancho II de Castela usurpou o trono ao irmão, Afonso VI de Leão, sendo de novo empossado na mesma quando este recuperou as duas coroas ${ }^{11}$, tal como acima referi. Esta fidelidade ao monarca pode ter justificado o já citado matrimónio com a Infanta, para mais tratando-se do chefe de uma linhagem que exercia o seu poder num vasto território.

Entretanto, Fernão Mendes I ter-se-á mantido à frente do governo da tenência flaviense, até que em 1084 surge a governá-la o conde Rodrigo Vasques $^{12}$. A razão desta ausência poderá estar no facto de ter acompanhado Afonso VI na campanha que culminou com a conquista de Toledo (1085), uma vez que num documento de 23 de Fevereiro de 1086 é de novo citado - Regnante rege Adefonso in Toleto, mandante Flavias Fernando Menendiz ${ }^{13}$.

Desde 1086 até 1112 não é possível saber a trajectória de Fernão Mendes I, nem mesmo se a notícia que se conhece para aquele último ano lhe diz respeito, ou antes ao seu neto homónimo. Antes, porém, de procurar esclarecer esta dúvida, terei ainda que referir a geração intermédia, corporizada por D. Mendo Fernandes de Bragança I, o qual poderá ter sido também senhor de Bragança ${ }^{14}$,

reconstruída (Grande Enciclopédia Portuguesa e Brasileira, Lisboa-Rio de Janeiro, Editorial Enciclopédia, vol. XXXII, p. $216, G E P B)$.

7 Krus, Luís: A Concep̧ãa Nobiliárquica do Espaço Ibérico. Geografia dos Livros de Linhagens Medievais Portugueses (1280-1380), Lisboa, Fundação Calouste Gulbenkian-JNICT, 1994, pp.70-71.

8 PiZARro, José Augusto de Sotto Mayor: Linhagens..., vol. I, p. 227-231.

9 Liber Fidei Sanctae Bracarensis Ecclesiae (ed. crítica de Avelino de Jesus da COSTA), 3 vols., Braga, Assembleia Distrital, 1965-1990, docs. 359 e 397 (LF).

${ }^{10} \mathrm{LF}$, doc. 401.

${ }_{11}$ Fernandes, A. de Almeida: Território..., pp. 237-238.

${ }_{12} L F$, doc. 412.

${ }_{13} L F$, doc. 400.

${ }_{14}$ Fernandes, A. de Almeida: Território..., p. 240, e MatToso, José: Ricos-Homens..., p. 66. Este último autor identifica-o ainda com um indivíduo homónimo que foi alferes-mor entre $1146 \mathrm{e}$ 1147. Creio, contudo, e tal como já referi noutro trabalho, que o alferes-mor se deveria identificar 
se é que não faleceu em vida de seu pai15.

Seja como for, Mendo Fernandes parece ter dado um importante contributo para a história da região que agora se estuda. $\mathrm{Na}$ verdade, não se pode deixar de valorizar o significado do seu casamento com Sancha Viegas, filha de D.Egas Gosendes, chefe da linhagem de Baião, uma das principais da nobreza portuguesa - tal como nos dizia o «Prólogo» do Livro Velho de Linhagens que há pouco citei- e que esteve directamente envolvida nos momentos decisivos da fundação da nacionalidade. Ora, este matrimónio, não pode deixar de significar o primeiro acto de uma gradual aproximação dos senhores de Bragança, e de todo o vasto território que senhoriavam — que desde sempre estivera claramente ligado às terras leonesas de Zamora_, à órbita portuguesa ${ }^{16}$.

Voltemos então a 1112. Em Março desse ano, Fernão Mendes I encontrava-se em Astorga, junto do conde D.Henrique ${ }^{17}$, o qual viria a falecer muito pouco tempo depois. Esta proximidade também é significativa, porque, articulada com o matrimónio de seu filho, mais acentua a ligação dos senhores Bragançãos ao partido portucalense, sobretudo numa fase em que o conde D.Henrique procurava alargar a base territorial do seu poder ${ }^{18}$.

Creio que este terá sido o último acto de Fernão Mendes I. A notícia seguinte é com toda a probabilidade relativa ao seu neto homónimo, D.Fernão Mendes de Bragança II, porventura a figura mais notável da linhagem. Recordado pelos textos linhagísticos medievais pelo seu carácter colérico e violento ${ }^{19}$, de há muito se aceita o seu papel decisivo para a integração de toda a região que os Bragançãos senhoriavam no território português ${ }^{20}$. Vejamos primeiro os factos relativos à sua trajectória política, para analisarmos depois os que mais directamente o ligam à história da região transmontana e alti-duriense.

A primeira referência documental que me parece dizer-lhe respeito data de 25 de Julho de 1124, e é relativa à doação do couto de Faiões, no concelho de

com Mem Fernandes de Bragança II, neto daquele (cfr. PiZARro, José Augusto de Sotto Mayor, Linhagens..,, vol.I, p. 241, nota c).

15 Com efeito, pode supor-se que, caso Fernão Mendes I ainda vivesse em 1112, atingiria uma razoável longevidade, uma vez que já era adulto em 1072, pelo que a morte do filho em vida do pai não seria de estranhar, o que também acabaria por explicar a total ausência de informações documentais para Mendo Fernandes I; se o documento de 1112 for relativo ao seu filho Fernão Mendes II, o que não me parece muito aceitável, mas que não é impossível, então mais parece ser de admitir o seu desaparecimento prematuro.

${ }^{16}$ Fernandes, A de Almeida: Território..., pp.238-241.

17 Documentos Medievais Portugueses-Documentos Régios, Volume I, Tomos I e II, Documentos dos Condes Portugalenses e de D. Afonso Henriques, A. D. 1095-1185 (ed. por Rui Pinto de Azevedo), Lisboa, Academia Portuguesa da História, 1958-1961, doc. n. ${ }^{\circ} 28$ (DMP-DR). Acredito que ainda fosse Fernão Mendes I (vd. nota 15), e não o seu neto homónimo, o qual me parece surgir apenas em 1124.

18 Fernandes, A de Almeida: Território .., pp.241-242.

19 LD12A3-4.

${ }^{20}$ Azevedo, Luís Gonzaga de: História de Portugal, vol.V, pp.137-138 e Fernandes, A. de Almeida: Território..., pp.242-246. 
Chaves, feita pela Rainha Dona Teresa a favor da Sé de Braga, e que Fernão Mendes II confirma ${ }^{21}$, provavelmente na qualidade de tenente das terras de Chaves, tradicionalmente governadas pela sua linhagem, como já tive a ocasião de referir. A partir de 1128 e até 1145 foi governador das terras de Bragança ${ }^{22}$, que terá acumulado com a tenência de Chaves-Montenegro até $1148^{23}$, tendo provavelmente vivido até $1160^{24}$.

Os seus dois matrimónios revestem-se também de um especial significado político. A sua primeira mulher, Teresa Soares, pertencia a uma das mais importantes linhagens portuguesas, a dos senhores da Maia, sendo filha de D. Soeiro Mendes da Maia, talvez o mais poderoso senhor do seu tempo, chefe da linhagem e grande apoiante do conde D. Henrique e da Rainha Dona Teresa ${ }^{25}$. Tendo enviuvado antes de 1130, Fernão Mendes II casou depois com a Infanta Dona Sancha, irmã de D. Afonso Henriques ${ }^{26}$.

Se as anteriores alianças matrimoniais referidas, com os de Baião, na geração anterior, e depois com os da $\mathrm{Maia}^{27}$, apontavam para uma aproximação clara dos Bragançãos à área de influência portuguesa, a referida ligação à família real revela-se inequívoca quanto à afirmação dessa tendência. Tendência manifestamente encorajada pelo nosso primeiro monarca que, ao entregar a mão de sua irmã, pretendia assim garantir a fidelidade e o apoio de uma linhagem que detinha um tão expressivo poder sobre um vasto território situado junto da fronteira com o reino de Leão ${ }^{28}$. Neste mesmo sentido se devem interpretar duas doações régias de 1144 e de 1145 , que beneficiaram o mosteiro de S. Salvador de Castro de Avelãs, cenóbio beneditino que gozava da protecção dos

${ }^{21}$ DMP-DR, doc. 67.

22 Ventura, Leontina: A Nobreza de Corte de Afonso III, vol.II, Coimbra, Faculdade de Letras, 1992, p.1010. No primeiro diploma, de 8 de Julho de 1128, e relativo a uma doação de terras sitas em Vinhais, é referido como Tenente Bragantia Fernando Menendiz (DMP, DR.91).

23 Azevedo, Luís Gonzaga de: História de Portugal, vol.V, p. 138, nota 1.

${ }^{24}$ MAtToso, José: Ricos-Homens..., p. 66.

25 Mattoso, José: Ricos-Homens..., pp. 51-52.

26 Talvez por volta de 1138, segundo A. de Almeida FernANDES, deduzindo que a sua confirmação de um documento desse ano $(D M P, D R .166)$ é o primeiro momento em que «nos aparece como um verdadeiro «português» (Guimarães, 24 de Julho de 1128 (Nos 850 Anos da Batalha de S.Mamede), Guimarães, 1978, p. 78), talvez porque o documento não se refere a nenhuma zona directamente ligada aos Bragançãos. Se não for esta a razão, desconheço porque faz aquela afirmação, e então o casamento até poderá ter ocorrido antes de 1135 (cfr. DMP, DR.103).

${ }_{27}$ Parece-me importante acentuar que nenhum dos outros filhos de Mendo Fernandes casou fora do âmbito português -e até se aliaram com linhagens altamente implicadas nos desígnios políticos de D. Afonso Henriques, como os de Cête ou os de Riba Douro- isto é, o casamento daquele com uma linhagem portuguesa parece ter afastado decisivamente a estirpe Bragançã da órbita leonesa, pelo menos pelo que é revelado pela estratégia matrimonial da linhagem (cfr. a árvore genealógica dos de Bragança, in PIZARRO, José Augusto de Sotto Mayor: Linhagens..., vol. III).

28 Azevedo, Luís Gonzaga de: História de Portugal, vol.V, p. 138, e Fernandes, A. de Almeida: Território..., pp. 243-244. 
senhores de Bragança, e ambas confirmadas pelo cunhado do monarca ${ }^{29}$; ou a entrega da estratégica tenência fronteiriça de Seia, pelo menos em $1132^{30}$, a Rui Mendes, um irmão de Fernão Mendes II que figurou na corte afonsina desde 1130 até $1135^{31}$. Em conclusão, foi através da aç̧ão de D.Fernão Mendes II, reforçada pelo seu casamento com a irmã do jovem monarca português, que definitivamente se agregou a Portugal o território de Bragança ${ }^{32}$.

Passemos agora a analisar os dados conhecidos sobre a actuação de Fernão Mendes II como senhor das terras brigantinas, os quais, como veremos, nos darão a verdadeira imagem do seu poder territorial.De resto, o primeiro diploma que irei citar espelha exemplarmente o que acabei de afirmar, revelando ainda como para os senhores de Bragança o rio Douro não representava a extrema meridional dos seus domínios. Com efeito, em 25 de Junho de 1130, acompanhado pelos seus filhos, e já então viúvo de Dona Teresa Soares da Maia, D.Fernão Mendes de Bragança II concedeu foral a Numão ${ }^{33}$. Pela descrição do termo que é outorgado a Numão, constata-se como a linhagem senhoreava toda a margem esquerda do Douro, desde um pouco a Ocidente de Numão até ao rio Águeda, numa enorme extensão que abrange toda a fronteira duriense dos actuais concelhos de Vila Nova de Foz Côa e de Figueira de Castelo Rodrigo ${ }^{34}$.

$29 D M P, D R$, docs. 207 e 210.

30 Ventura, Leontina: A Nobreza ..., vol. II, p. 1022.

31 Mattoso, José: Ricos-Homens..., p. 66. Segundo este autor, e de acordo com a cronologia conhecida para Rui Mendes, parece ser verosímil uma referência linhagística sobre os dois irmãos, segundo a qual Fernão Mendes teria cegado e morto Rui Mendes, por este não ter respeitado um pacto jurado entre ambos no mosteiro de Moreruela (LD12A3, ref. em IDEM, ibidem).

32 Azevedo, Luís Gonzaga de: História de Portugal, vol.V, pp.137-138; FernAndes, A. de Almeida: Território..., pp. 244-245 e 252-253, e Guimarães..., p. 78, nota 1.

33 Portugaliae Monumenta Historica, Leges et Consuetudines, vol. I, Lisboa, Academia Real das Sciencias, 1856-1868, pp.368-370. Segundo Luís Gonzaga de Azevedo, a postura de Fernão Mendes, relativamente à sua adesão ao partido de D.Afonso Henriques, era então «ainda vacilante», pois que fez menção a Afonso VII - Regnante Rege Alfonso in Legione et in tota stremadura imperante portugal Infante domno Alfonso (História de Portugal, vol.V, pp.137 e 138, nota 1). O problema, a meu ver, é que naquele momento Fernão Mendes se encontrava numa posição um pouco dúbia, isto é, se por um lado era, desde 1128, tenente de Bragança por D.Afonso Henriques, e nessa mesma condição confirma o foral que outorgara - potestas in Bragantia et in Lampazas Fernando Menendiz -, também é verdade que, por outro, o território situado para leste do Távora se encontrava sob a jurisdição leonesa. Isso mesmo transparece pela própria invocação dos dois senhores a quem Fernão Mendes se encontrava ligado pelos domínios que detinha. As referências bibliográficas sobre esta concessão abundam, pelo que apenas referirei as mais significativas, para além daquela que já acima foi citada: GEPB, vol. XIX, p.15; FerreIrA, J.A. Pinto: Antiguidades de Numão, Porto, 1953, p. 41; Azevedo, Rui Pinto de: «Riba Côa sob o domínio de Portugal no reinado de D. Afonso Henriques. O Mosteiro de Santa Maria de Aguiar, de fundação portuguesa e não leonesa», in Anais (da Academia Portuguesa da História), II. ${ }^{a}$ Série, vol.12 (1962), p. 259, nota 28; NETO, Joaquim Maria: $O$ Leste do Território Bracarense, Torres Vedras, 1975, p. 103; e Gomes, Paulo Dordio: «O Povoamento...», p. 186, nota 4.

34 GEPB, vol. XIX, p.17. 
Este documento, para além de reforçar o que já ficou dito sobre o poder da linhagem, uma vez que são raros os casos de concessão privada de cartas de foral, revela-nos também a acção que a mesma teve no (re)povoamento de diversas zonas ${ }^{35}$ e, acrescente-se, na senhorialização das mesmas, como fica claro através de algumas das disposições foralengas, tais como as relativas à fossadeira, à reserva de uma parte dos baldios, ou à protecção dos criminosos que se acolhessem sob a protecção do senhor, entre outras ${ }^{36}$.

Continuando agora a analisar a acção dos senhores de Bragança no vale superior do Douro, terei que referir a concessão do foral de Freixo de Espada-àCinta. Muito embora aquela concessão, datada de 1 de Janeiro de [1155$1157]^{37}$, seja de iniciativa régia, o seu formulário encerra um dado de inquestionável interesse para a história da região e da linhagem que a senhoreava. Com efeito, o monarca afirma expressamente que outorga o foral, «per consilium de Fernam Melendis», isto é, com a autorização do prócere brigantino, que assim via legitimada pelo seu régio cunhado a autoridade que exercia, com contornos muitíssimo dilatados, no território transmontano ${ }^{38}$.

Finalmente, e agora segundo as Inquirições de 1258, ficara também a deverse a Fernão Mendes II o povoamento da vila de Santo Estêvão (fg. de Santa Cruz da Vilariça no julgado do mesmo nome ${ }^{39}$ ); no tempo de D. Afonso II, os seus povoadores tornaram-se homens da Ordem do Hospital ${ }^{40}$. Esta referência às ordens militares é importante, porque me permite acentuar uma característica interessante do papel dos Bragançãos, enquanto agentes de povoamento e, especialmente, de senhorialização do território transmontano. Com efeito, são bastante abundantes as referências aos domínios daquelas instituições monástico-militares na região, sobretudo em relação aos Hospitalários e aos Templá-

35 Muito embora este primeiro ponto seja dedicado à zona da margem direita do Douro, tive que abrir esta excepção a propósito do povoamento de Numão, por um lado, porque é a primeira referência conhecida sobre a acção de Fernão Mendes II e, por outro, para deixar desde logo bem clara a ideia de que a mesma também se processou na margem esquerda daquele rio, como depois veremos no ponto seguinte a propósito de Longroiva ou de Trevões.

${ }^{36}$ PMH, Leges, pp.368-370.

37 PMH, Leges, pp.378-381 (com o ano de 1152, tal vez errado, cfr. DMP, DR, doc. 252). A doação foi confirmada, entre outros, por D. Pero Fernandes, que eu suponho seja filho de D. Fernão Mendes II.

38 Este caso não é o único relativo a D. Fernão Mendes. Com efeito, em 1147, D. Afonso Henriques concede uma carta de doação e couto de um casal sito no concelho de Chaves, a favor da Sé de Braga, com a autorização de seu cunhado e de sua irmã, a Infanta Dona Sancha: «Et facio vobis similiter cautum de ipsa villa per suos terminos concedente domno Fernando Menendiz et uxor sua infantissa domna Santia» ( $L F$, doc. 540).

39 Sobre este antigo julgado, cuja metade meridional foi integrada no actual concelho de Torre de Moncorvo, veja-se o excelente artigo, que eu suponho seja da autoria de A. de Almeida FERNANDES, na GEPB, vol. XXXII, pp.214-221).

40 Portugaliae Monumenta Historica, Inquisitiones, Vol.I, Parte I e II, Lisboa, Academia Real das Sciencias, 1888-1977, p.1274. 
rios, sendo que alguns deles, e por vezes bem importantes, tinham sido obtidos pela liberalidade de vários membros daquela linhagem. É o caso, deveras elucidativo, da doação feita por D. Fernão Mendes II a favor da Ordem do Templo, da vila e da igreja de S. Mamede de Mogadouro, bem como do castelo de Penas Róias, «quod domnus Fernandus Menendi dedit eam Ordini Templi quando tenebant terram de manu domni Regis» ${ }^{41}$.

Fernão Mendes II não teve filhos da sua união com a Infanta Dona Sancha - o que leva a admitir que por via da sua herança tenham ingressado na coroa alguns dos bens dos Bragançãos ${ }^{42}$ - mas teve-os de Dona Teresa Soares da Maia. Se destes nos interessa mais especialmente D. Pero Fernandes, nem por isso se pode deixar de referir D. Mendo Fernandes de Bragança II, pese embora a circunstância de não se conhecer qualquer dado que o associe ao território «paterno». O facto, porém, de ter sido o alferes-mor de D. Afonso Henriques entre 1146 e 1148 , ou seja, num período particularmente difícil da reconquista afonsina, coincidente com as conquistas de Santarém e de Lisboa, não pode deixar de revelar, para além do seu presumível valor militar, a inquestionável confiança que o monarca depositava nos senhores de Bragança. Deverá ter permanecido na corte depois de 1148 até 1156 ou 1157, ano a partir do qual, e até 1169 , foi de novo alferes-mor, mas ao serviço de Fernando II de Leão ${ }^{43}$. A presença junto do monarca leonês permite destacar, não direi uma característica, mas antes uma faceta interessante da linhagem, ou seja, a relativa facilidade e frequência com que os senhores de Bragança se colocavam ao serviço do reino vizinho, aproveitando as circunstâncias políticas e o posicionamento estratégico do território onde eram senhores praticamente incontestados, para obterem benefícios e poder de um e do outro lado da fronteira ${ }^{44}$.

Quanto a D. Pero Fernandes, foi o continuador de seu pai ${ }^{45}$, como governador de Bragança (1165-1187), mas também de Viseu (1186) ${ }^{46}$, destacando-

${ }^{41}$ PMH-Inq., pp. 1278 e 1279 (cfr. Gomes, Paulo Dordio, «O Povoamento ...,», p. 174).

42 Ver sobretudo Fernandes, A. de Almeida: Guimarães ..., p. 78, nota 1.

43 Mattoso, José: Ricos-Homens..., p. 67, e Ventura, Leontina, A Nobreza..., vol. II, p. 991. Aquele autor entendia que estes dados se reportariam a Mendo Fernandes I, mas estou convencido, tendo em conta as cronologias relativas a Fernão Mendes II, que só poderia ser o filho deste e não o pai (cfr. PizArro, José Augusto de Sotto Mayor, Linhagens..., vol. I, p. 242, nota g). Ainda quanto à sua presença em Leão, como alferes-mor, v.g. TORRES SEviLLA-QUiÑONES DE LEÓN, Margarita: Linajes Nobiliarios en León y Castilla (Siglos IX-XIII), León, Junta de Castilla y León, 1999, p. 448.

${ }_{44}$ Mattoso, José, Ricos-Homens..., p. 72.

${ }_{45}$ Mendo Fernandes desaparece da documentação depois de 1169 e, muito embora tenha tido descendência, o ramo a que deu origem caiu em total esquecimento (LV2T7). No entanto, é possível, atendendo ao nome, à cronologia e à localização dos bens, que fosse seu filho um Pero Mendes, dito Tyo, que se encontra documentado em Julho de 1172, quando recebe de D. Afonso Henriques o reguengo de Atenor e de Palaçoulo (freguesias do concelho de Miranda do Douro), para povoar - facio vobis nostro militi Petrus Menendiz et cognominatus Tyu - o que foi confirmado por D. Pero Mendes de Bragança (DMP, DR.312 - ref. in GEPB, vol. XXXVIII, p. 645).

46 Ventura, Leontina: A Nobreza ..., vol.II, pp. 1010 e 1025, respectivamente. 
se sobretudo por ter ocupado o mais importante cargo áulico, como mordomomor de D. Afonso Henriques e do Infante D. Sancho, entre 1169 e 1175, estando documentado na corte até $1194^{47}$.

O seu casamento situa-se também a um nível que já se pode considerar «tradicional» na sua linhagem, isto é, ao nível da família real. E, como é óbvio, não existe coincidência no facto de a sua mulher, Dona Fruilhe Sanches, ser filha de D. Sancho Nunes de Barbosa e da Infanta Dona Sancha, irmã de D. Afonso Henriques, o mesmo é dizer, filha do primeiro casamento da segunda mulher de seu pai, D. Fernão Mendes de Bragança II...

D. Pero Fernandes e a condessa Dona Fruilhe Sanches são diversas vezes referidos pelas Inquirições de 1258, como proprietários em vários julgados transmontanos, tendo beneficiado a Ordem do Hospital com várias doações de vulto $^{48}$. Para a região que nos importa, sabe-se por aquelas fontes que o mosteiro de Bouro detinha a vila e a igreja de Santa Comba da Vilariça, por doação feita por aquele casal ${ }^{49}$.

Aproximando-nos já do século XIII, e antes de continuar a acompanhar a evolução da linhagem dos de Bragança, convirá referir outras linhagens presentes na região transmontana ainda durante o século XII. Não são muitas, desde já o direi, de tal forma se impunha o poder quase hegemónico dos Bragançãos, apenas ladeado pela presença das ordens militares do Hospital e do Templo —o que em grande medida se devia às doações recebidas da parte daqueles senhores-e de alguns mosteiros, entre os quais se destacavam o de Castro de Avelãs e o de Moreruela ${ }^{50}$, ambos, diga-se, também a eles muito ligados.

Antes de mais, uma referência aos senhores de Riba Douro, linhagem que teremos oportunidade de conhecer melhor quando se analisar o território a sul do Douro, mas para a qual também se conhece uma referência para a região de Moncorvo. Quando, em 1182, D. Afonso Henriques concedeu foral a Urros, é referido

${ }^{47}$ Mattoso, José: Ricos-Homens..., pp.66-67, e Ventura, Leontina, A Nobreza..., vol. II, pp.988. O seu aparecimento na corte, porém, e segundo creio, poderá ter ocorrido numa data anterior a 1165 , porquanto deverá ser o D. Pero Fernandes que surge como primeiro confirmante do foral concedido a Mós (de Moncorvo), de Dezembro de 1162 (DMP, DR.284). Se assim for, e atendendo à região do foral, já então poderia ser tenente de Bragança. Por outro lado, é possível que uma vez ou outra tenha estado ao serviço do rei leonês Afonso IX, surgindo em 1193 como tenente Extrematuram (cfr. Alfonso ANTÓN, Isabel: La colonización cisterciense en la Meseta del Duero. El Dominio de Moreruela (Siglos XII-XIV), Zamora, Instituto de Estudios Zamoranos «Florián de Ocampo», (C.S.I.C.), 1986, pp. 336-337, se não mesmo entre 1190 e 1195 (TORRES SEVILLAQUIÑNONES DE LEÓN: Margarita, Linajes..., p. 463).

${ }^{48} \mathrm{~A}$ maior parte das informações diz respeito às terras de Mirandela e de Ledra, bem como ao couto de Sambade, no julgado de Alfândega da Fé (cfr. PiZARro, José Augusto de Sotto Mayor, Linhagen..., vol. I, p. 232).

49 PMH-Inq., pp.1274-1275 (hoje no concelho de Vila Flor, mas então no julgado de Santa Cruz da Vilariça, que era encabeçado por Torre de Moncorvo).

50 Sobre o património de Moreruela nesta região, veja-se o excelente trabalho de ALFONSO ANTÓN, Isabel: La colonización..., pp. 109, 115, 124, 132 e 146. 
como dominum ville Fernam Velaz ${ }^{51}$. Trata-se de D. Fernão Veilaz de Riba Douro, bisneto de D. Egas Moniz, o Aio, que assim nos surge como senhor de Urros. Tendo em conta o afastamento desta linhagem em relação a este território, é de admitir que a sua presença se ficasse a dever a alguma aliança matrimonial com os Bragançãos, sua ou de seu pai ou de seu avô, o que infelizmente não se pode comprovar por ausência de dados relativamente a este ramo dos de Riba Douro. A hipótese, porém, é bastante plausível, tendo em conta as ligações frequentes entre as duas linhagens, a partir da geração dos filhos de Mem Fernandes I ${ }^{52}$.

Ainda há pouco referi que o mosteiro zamorano de Moreruela detinha vários bens no território transmontano. Para além desta presença de um importante senhorio monástico leonês, também se conhecem referências à posse de bens na mão de senhores laicos para os séculos XII e XIII. Assim, conhece-se a doação de Angueira (hoje fg. do c. de Vimioso, mas então referida na terra de Miranda), feita em [1195-1198] por D. Sancho I a favor do nobre zamorano D. Telo Fernandes ${ }^{53}$. Esta doação, e tal como o sublinhou Paulo Dordio Gomes, poderia corresponder a uma tentativa do monarca para aliciar nobres leoneses a povoarem e defenderem territórios junto da fronteira contra investidas do rei leonês, tal como sucedeu com a freguesia de Malhadas, na terra de Miranda, entregue pelo mesmo monarca a um grupo de nobres zamoranos, com a finalidade explícita de eles defenderem Bragança, caso esta fosse atacada ou cercada, acordo que foi selado por um pacto ${ }^{54}$.

A preocupação régia com a defesa e o povoamento de todo este território, especialmente aquele que mais de perto confinava com a linha de fronteira, acabava por se traduzir por uma política de concessão de forais, que D. Afonso Henriques encetara e à qual D. Sancho I deu continuidade. Política essa que, por outro lado, também originava a criação e o desenvolvimento de algumas «clareiras» concelhias, num território bastante senhorializado desde a sua integração em Portugal, tal como temos vindo a observar, mas que em certos casos contou com a anuência dos senhores de Bragança ${ }^{55}$.

${ }^{51}$ PMH, Leges, pp.424-426.

52 Com efeito, um irmão de Fernão Mendes II, Nuno Mendes, casou com uma sobrinha do Aio, o mesmo acontecendo com uma filha de Pero Fernandes, para além de um outro bisneto de Egas Moniz, Fernão Pires de Lumiares, que casou duas vezes com senhoras da linhagem Bragançã (cfr. PiZARro, José Augusto de Sotto Mayor: Linhagens..., vol.III, árvores genealógicas dos de Bragança e dos de Riba Douro).

${ }_{3} 3$ Documentos da Chancelaria de D. Sancho I (1174-1211) (ed. por Rui de AzEvedo, Avelino de Jesus da Costa, e Marcelino PereirA), Vol.I, Coimbra, Universidade de Coimbra, 1979, doc. 113 $(D S)$. Bastantes anos depois, os seus herdeiros venderam metade de Angueira «de Miranda» ao mosteiro de Moreruela por 380 morabitinos (doc. de Setembro de 1246, publ. por Alfonso ANTÓN, Isabel: La colonización..., doc.117, pp.431-432), o que é expressamente referido pelos inquiridos de 1258 (cfr. PMH, Inq., p. 1283).

${ }^{54}$ PMH, Inq., p. 1283 (cit. por GoMES, Paulo Dordio, «O Povoamento...», p. 175, e também ref. in GEPB, vol. XVI, p. 17).

55 Cfr. Gomes, Paulo Dordio: «O Povoamento ...», pp. 173-176. 
Por momentos interrompida para conhecermos outros intervenientes no processo da senhorialização transmontana, retomemos então a evolução da linhagem que mais a protagonizou.

D. Pero Fernandes de Bragança teve vários filhos ${ }^{56}$, alguns dos quais também estão documentados na corte de D. Sancho I. Domno Garcie Petri bragantiano ${ }^{57}$, presumivelmente o mais velho, ali se encontra entre 1186 e 1205 , tendo mesmo sido beneficiado pelo monarca com a doação de vários herdamentos; quer estes quer os que terá recebido por herança, revelam um património — do qual fez algumas doações aos freires Hospitalários- essencialmente localizado nas terras de Mirandela e de Ledra ${ }^{58}$, onde o seu domínio deveria ser tão marcante que ficou cognominado como o Ledrã $0^{59}$. O seu prestígio fica também acentuado pelo seu casamento com Dona Gontinha Soares de Tougues, de uma linhagem também muito ligada à corte de D. Afonso Henriques e de D. Sancho ${ }^{60}$, e do qual houve descendência.

Desta, convirá reter dois aspectos: por um lado, as alianças matrimoniais contraídas com linhagens leonesas ${ }^{61}$, significando que os Bragançãos nunca cortaram radicalmente os seus laços com a terra originária, a qual, como a seguir se verá, sempre representou um refúgio quando a linhagem atravessou situações políticas mais delicadas; por outro, as violências e os abusos senhoriais cometidos.

Com efeito, os senhores de Bragança tinham surgido até Fernão Mendes II como magnates incontestados de todo este território, cujo poder ali ombreava com o dos próprios monarcas, sendo mesmo de sublinhar a sua acção enquanto protagonistas de algumas medidas repovoadoras. Agora, porém, as fontes começam a deixar notícias sobre actos de violência, ou de atitudes de prepotência

56 A dispersão dos bens dos filhos de Pero Fernandes, deixa perceber como os domínios dos senhores de Bragança se espraiavam por todo o território transmontano e alti-duriense, desde Montenegro e Sabrosa, até Bragança, Mirandela ou Miranda, já para não falar dos que ultrapassavam a linha do Douro até Trancoso ou Pinhel (cfr. PizArro, José Augusto de Sotto Mayor: Linhagens..., vol. I, pp. 232-240). Por outro lado, o poder e o prestígio da linhagem também ficam bem patentes pela categoria das suas alianças matrimoniais: Garcia Pires com uma de Tougues, Fernão Pires com uma dona das Asturias, Vasco Pires com uma de Baião, Sancha Pires com um Riba Douro, e Teresa Pires com o chefe da linhagem de Baião, depois de ter sido barregã do Infante Afonso de Molina, filho de Afonso IX de Leão (cfr. IDEM, ibidem, vol. I, pp. 232, 235 e 237).

57 PMH, Inq., p. 1267.

58 Sobre este indivíduo e o seu património, v.g. PizArro, José Augusto de Sotto Mayor: Linhagen, vol.I, p. 232.

59 Sobre a possível deturpação deste cognome, cfr. IDEM, ibidem, nota 24.

${ }^{60}$ IDEM, ibidem, vol. II, p. 283-291.

${ }^{61}$ Pero Garcia casou com uma senhora de nome Sancha Osorez - patronímico do nome Osorio, praticamente inexistente na onomástica portuguesa e bastante frequente na leonesa-, Teresa García com um Fernão Pires Manrique, e Elvira García com um Ordonho Álvares das Asturias (cfr. IDEM, ibidem, vol.I, pp. 232-235). 
senhorial perpetradas pelos seus membros ${ }^{62}$. Foi o caso de Pero Garcia, filho de Garcia Pires, que cometeu violências contra os moradores de Mirandela, ou de seu filho Martim Pires Tavaia — nascido de uma ligação incestuosa de Pero com a sua irmã Mor Garcia (LL24E4)_ que no tempo de D. Sancho II obrigou o concelho de Santa Cruz da Vilariça a dar-lhe a herdade reguenga de Rio Merdeiro, que ao tempo das Inquirições de 1258 estava na posse de sua mulher e de seus filhos ${ }^{63}$.

Outros filhos de Pero Garcia foram: Vasco Pires, o Veirão, também documentado entre 1196 e 1205 na corte de D. Sancho I, com quem teve uma contenda devido às violências que exercia contra propriedades do mosteiro de Bouro, situadas em terras transmontanas ${ }^{64}$; Nuno Pires, sobretudo documentado para a zona de Sabrosa e de Lamas de Orelhão ${ }^{65}$; e Fernão Pires, sobre quem não se conhece qualquer informação, para além de ter sido «casado com uma dona das Asturias» (LV2U8), mas que para nós tem um especial interesse, pois foi o pai de uma figura política de relevo, e bastante ligada à região em estudo.

$\mathrm{Na}$ verdade, e por razões que se desconhecem, parece ter sido D. Fernão Fernandes de Bragança que sucedeu a seu avô na chefia da linhagem. Pelo menos, é o que leva a supor o facto de surgir como tenente de Bragança a partir de 1192, ou seja, ainda em vida daquele. A importância da sua trajectória política fica bem patente nos diferentes cargos que ocupou ao longo de vários anos, quer no reino português quer no reino de Leão. Assim, foi rico-homem das cortes de D. Sancho I, de D. Afonso II e de D. Sancho II, como tenente de Bragança (1192-1204 e 1218-1232), de Baião (1197), de Penaguião (11971202), e de Panóias (1197-1202, 1218 e 1226-1229), tendo chegado a ocupar o importante cargo de alferes-mor de D. Sancho II, entre 1225 e $1226^{66}$.

Os hiatos cronológicos que se registam no exercício de algumas tenências, especialmente na de Bragança, poderão levantar alguma suspeita a um leitor mais atento. E, com efeito, eles revelam, entrados já no século XIII, uma profunda alteração das relações entre a Coroa e os senhores de Bragança. Creio bem, como já tive ocasião de afirmar num outro trabalho, que essa alteração se terá ficado a dever às rivalidades que os deveriam opor à poderosa linhagem de

62 Evidentemente que não esqueço o considerável rol de episódios violentos protagonizados por Fernão Mendes II, descritos em pormenor pelos textos linhagísticos. Contudo, esses episódios reflectem os traços violentos do seu carácter, mas não referem qualquer caso de exercício de abusos contra dependentes seus (cfr. MATTOSO, José, Ricos-Homens..., pp. 65-66).

63 PMH, Inq., pp. 1267-1268 e 1274, respectivamente (ref. por José Augusto de Sotto Mayor PiZArro: Linhagens..., vol. I, pp. 232-233). Recorde-se ainda o exemplo de D. Pero Fernandes, excomungado pelo arcebispo de Braga D. João Peculiar, por ter usurpado albergarias e outros bens da Sé de Braga sitos em Trás-os-Montes ( $L F$, doc. 419).

${ }^{64} D S$, doc. 216.

65 PIZArro, José Augusto de Sotto Mayor: Linhagens..., vol. I, pp. 236-237.

66 IDEM, ibidem, vol. I, p. 235. 
Sousa ${ }^{67}$. Seja como for, o certo é que a partir de 1204 Fernão Fernandes desaparece da corte portuguesa —o que sucederá a seus tios Garcia e Vasco Pires a partir de 1206- surgindo a partir de então junto de Afonso IX de Leão, quer como tenente (1204-1205 e 1206-1222), quer como alferes-mor (1211), quer mesmo como mordomo-mor (1219-1222) ${ }^{68}$. Tenente da Extremadura, bem como de Villafáfila e de Zamora, acompanhou o monarca leonês em diversas ocasiões, sendo de destacar a sua presença na célebre batalha das Navas de Tolosa, em $1212^{69}$, por cujos serviços foi recompensado por Afonso IX, que em 1214 lhe fez uma importante doação, pro bono et grato servicio quod mibi fecistis in terra serracenorum et aliis multis locis ${ }^{70}$.

A partida para o reino de Leão, porém, não significou o exílio definitivo de Fernão Fernandes. Com efeito, o que se passou foi uma permanente entrada e saída do reino, servindo ora o monarca leonês ora o monarca português, obtendo assim vantagens de um e do outro lado da fronteira. Tendo regressado a Portugal em 1218, já com D.Afonso II, foi alferes-mor de D.Sancho II, conservando o governo das terras de Bragança até à sua morte, que terá ocorrido depois de 1232.

Quanto às suas ligações patrimoniais com a região transmontana, conhecem-se alguns dados importantes. Assim, em 1196, D.Sancho I doa-lhe a vila de Vimioso, na terra de Miranda, «pro bono servicio quod nobis fecistis» ${ }^{71}$, vila que Fernão Fernandes povoou, assim como a de Ifanes, mas que acabaria por doar, bem como outros bens, beneficiando quer senhor laicos ${ }^{72}$, quer monásticos, destacando-se entre estes o já referido mosteiro leonês de Moreruela ${ }^{73}$.

67 IDEM, ibidem, vol. I, pp. 229-230.

68 IDEM, ibidem, vol. I, p. 235. Note-se que Fernão Fernandes já tinha sido tenente em Leão entre 1193 e 1194, tal como o seu tio Garcia Pires tinha sido mordomo-mor do mesmo monarca em 1196.

69 GonZÁLEZ, Julio: Alfonso IX, vol. I, Madrid, CSIC, 1944, pp. 134-135, 153, 179 e 360-361.

70 IDEM, ibidem, vol. II, doc. 300.

71 DS, doc. 97 (doação confirmada, entre outros, pelos tios de Fernão Fernandes, Garcia e Vasco Pires, e que também contemplava a vila de Sezulfe, na terra de Ledra).

72 Segundo as Inquirições de 1258, Fernão Fernandes doou a vila de Vimioso a D. Pero Ponces de Leão, estando então na posse da sua viúva e dos seus filhos (PMH, Inq., pp.1182-1183 e $1184-$ 1185); sobre D. Pero Ponces, que também povoou a vila de Biberes [Campo de Víboras], na terra de Miranda, PMH, Inq., pp.1280-1281; v.g. TORRES SEVILlA-QuiÑoneS DE LeÓn, Margarita: Linajes..., p. 191).

73 Segundo a mesma fonte, a vila de Ifanes era do rei, mas Fernão Fernandes tinha-a usurpado, dando-a ao mosteiro de Moreruela no tempo de D. Afonso II (PMH-Inq., pp.1280-1281). Também a igreja e vila de Braciosa era dividida entre a Ordem do Hospital e Moreruela, por doação do mesmo senhor (PMH-Inq., pp.1282-1283). Era grande a ligação de Fernão Fernandes a Moreruela, tendo-lhe feito, por volta de 1204, uma importante doação em terras e em dinheiro (ALFONSO ANTÓn, Isabel: La colonización..., pp. 346-347, doc. 48). Também a Moreruela fez diversas doações Afonso Mendes de Bornes, cavaleiro, de bens sitos em Genísio e em S. João de Angueira, na terra de Miranda, entre 1255 e 1260 (IDEM, ibidem, docs. 136, 137, 143 e 145). Uma análise muito detalhada destas relações entre a nobreza e cenóbios localizados em ambos os lados da fronteira 
A história da linhagem dos Bragançãos está quase a chegar ao seu termo. Poucos anos depois da morte de D. Fernão Fernandes, surge à frente do governo das terras de Bragança, entre 1237 e 123874, D. Fernão Garcia, seu sobrinho e filho de D. Garcia Pires. Seria este o último Braganção, descendente do fundador da estirpe por linha legítima, a ocupar um cargo curial. Envolvida nos sucessos políticos que marcaram o conturbado reinado de D. Sancho II, a linhagem acabaria por desaparecer da cena política, tendo o seu último representante, Gonçalo Nunes, neto de D.Vasco Pires, vivido a maior parte da sua vida exilado na corte do rei Afonso X de Castela, mas, por ironia do destino, acabaria os seus dias assassinado, em Bragança ${ }^{75}$.

Durante o exílio de Gonçalo Nunes, porém, a representação da linhagem fora reivindicada por um seu parente, Nuno Martins de Chacim, neto, por via feminina e bastarda, de Nuno Pires de Bragança, filho de D. Pero Fernandes. Armado cavaleiro por D.Fernão Garcia (LL38B6), e filho de Martim Pires de Chacim, membro de uma linhagem menor que seguramente estava ligada pela vassalagem aos Bragançãos, Nuno Martins soube valer-se daquela ausência e do favor régio conseguido junto de D. Afonso III, para ir ocupando uma boa parte das terras e do posicionamento detidos outrora pela linhagem de sua mãe ${ }^{76}$.

Antes de o referir, porém, uma vez que com Nuno Martins atingiremos o final desta primeira parte dedicada ao território a norte do rio Douro, vejamos outras linhagens que entretanto foram surgindo na região. $\mathrm{Na}$ verdade, se durante o século XII dificilmente se encontrava outra linhagem, que não a dos Bragançãos, na parte do território transmontano que agora se analisa - e mesmo nessa eventualidade, excepção feita a um de Riba Douro, por ligação ao território leonês_-, a entrada no século XIII parece ter aberto o território a outras linhagens, muito embora essa presença possa ter ocorrido à sombra da velha estirpe bragançã.

Parece ser o caso, com efeito, de D. Ponço Afonso de Baião, a quem os mora-

encontra-se em vários trabalhos de BECEIRO PITA, Isabel: «Las tensiones en torno a los dominios del Cister gallego en el norte de Portugal (1247-1357)», in Congreso Internacional sobre San Bernardo e o Cister en Galicia e Portugal. Actas, vol. I, Ourense, 1992, pp. 253-265; «La Memoria de las propriedades y derechos señoriales: las posesiones del Cister gallego-leonés en el norte de Portugal (1258-1365)», in Temas Medievales, n. ${ }^{\circ} 2$ (1992), Buenos Aires, pp.15-33; e, sobretudo, «Los poderes señoriales en los territórios fronterizos al norte del Duero (siglo XIII- inicios del XIV), in Revista da Faculdade de Letras, História, II. ${ }^{a}$ Série, vol.XV (1998), Porto, pp. 1085-1100

74 VenturA, Leontina: A Nobreza..., vol. II, p. 1010.

${ }^{75}$ LV2B9. Também um seu parente, neto por bastardia de Nuno Martins de Chacim, Nuno Rodrigues Bocarro, foi morto em Riba Doiro, sobre Miranda, a par de uns moinhos u andava em companha de D. Alvaro Nuniz de Lara, e ia em partimento de uma peleja (Portugaliae Monumenta Historica. Nova Série, Vol. II/1-2, Livro de Linhagens do Conde D. Pedro de (ed. por José MatToso), Lisboa, Academia das Ciências de Lisboa, 1980, LL38S10).

76 Sobre o início da linhagem de Chacim, bem como o início da carreira de Nuno Martins, v.g. PiZARro, José Augusto de Sotto Mayor: Linhagens..., vol. I, pp. 243-247, e VenturA, Leontina, A Nobreza..., vol. II, p. 626. 
dores da vila de Santa Cruz da Vilariça deram herdades e casas onde ele fez um moinho, e que à data das Inquiriz̧ões de 1258 estavam na posse dos seus filhos ${ }^{77}$. A presença, porém, deste conhecido rico-homem das cortes de D. Sancho I, D. Afonso II e D. Sancho II em território braganção, explica-se bem, uma vez que a sua mãe, Dona Teresa Pires, era filha de D. Pero Fernandes de Bragança ${ }^{78}$.

Sem que se possa descortinar uma ligação directa com os senhores de Bragança, sabe-se que Mem Guedaz teve a terra de Ulgoso em nome do Rei, levando o montádigo de toda a terra de Miranda ${ }^{79}$. Desconhece-se a cronologia destes factos, mas é talvez possível identificá-lo com Mem Guedaz Guedeão II, que terá vivido na segunda metade do século XII, ou entre o último quartel dessa centúria e o primeiro quartel de Duzentos, e que pertencia a uma linhagem oriunda das altas terras de Basto e de $\mathrm{Chaves}^{80}$, pelo que poderiam existir ligações entre Guedãos e Bragançãos que se desconhecem ${ }^{81}$.

Já o caso de Martim [Pires] Correia, que foi tenente de Aguiar da Pena em $1257^{82}$, e que, ainda segundo as Inquiriz̧ões de 1258, tinha filhado uma herdade na vila de Freixo de Espada-à-Cinta ${ }^{83}$, talvez se possa explicar a sua presença nestas paragens por ser cunhado de D. Nuno Martins de Chacim, casado em primeiras núpcias com a sua irmã Sancha Pires Correia. Também associados a D. Nuno Martins, são referidos pela mesma fonte dois irmãos, Fernão e Rui Pais, seus sobrinhos, que teriam povoado a vila de S. João, na terra de Miranda ${ }^{84}$.

Vejamos então quem foi D. Nuno Martins de Chacim. A sua biografia foi recentemente estudada, pelo que me limitarei a referir os dados mais pertinentes ${ }^{85}$. Primeiro meirinho-mor do Reino, entre 1261 e 1276, ascendeu a rico-homem a

77 PMH-Inq., pp.1274-1275. Também nas Inquirições de 1288-90, D. Ponço é referido a propósito do então vizinho julgado de Vilarinho da Castanheira (hoje fg. do c. de Carrazeda de Ansiães), onde aquele rico-homem ganhara umas casas e uma herdade, que honrara, na aldeia de Vilarinho, à data na posse de seu neto D. Lourenço Soares de Valadares (cfr. PIZARRO, José Augusto de Sotto Mayor: Linhagens..., vol. II, pp. 196-198).

${ }_{78}$ Cfr. IDEM, ibidem, vol. I, pp. 293-294 e 299. De resto, um dos seus primos, Afonso Lopes, filho de D. Lopo Afonso, também detinha bens em Bragança (para uma visão global do património desta linhagem, v.g. Ventura, Leontina: A Nobreza..., vol. II, pp. 599-608 e os respectivos quadros e mapa nos Anexos à Prosopografia).

79 PMH, Inq., pp. 1280-1281.

${ }^{80}$ Cfr. PiZArRo, José Augusto de Sotto Mayor: Linhagens..., vol. II, pp. 9-10.

${ }^{81}$ A mãe de Nuno Martins era meia-irmã de D. Fernão Fernandes Cogominho, filho de um primo co-irmão de Mem Guedaz, e que chegou a deter parte da vila de Chacim, pelo que não será difícil adivinhar outras ligações parentais (cfr. IDEM, ibidem, vol. I, p. 246, nota 15).

82 IDEM, ibidem, vol. II, p. 395.

${ }^{83}$ PMH-Inq., p. 1278.

${ }_{84}$ PMH-Inq., p. 1282-1283 e 1284-1285. Creio que será a fg. de Sanhoane, no c. de Mogadouro. Quanto à linhagem dos dois irmãos, é possível que fossem filhos de alguma irmã de D. Nuno Martins, ou seus primos co-irmãos, uma vez que, neste período, a terminologia do parentesco é por vezes bastante vaga.

85 Ventura, Leontina: A Nobreza..., vol. I, pp. 96-100, 111 e 339-340, e vol. II, pp. 626630; PizArro, José Augusto de Sotto Mayor: Linhagens..., vol. I, pp. 246-247. 
partir de 1265, data em que assumiu a tenência de Bragança e que deteve até 1284; aio de D. Dinis, foi depois o seu mordomo-mor, desde que aquele subiu ao trono, em 1279, até à sua morte, em 1284. Está sepultado no mosteiro de Castro de Avelãs, centro espiritual e simbólico dos velhos Bragançãos.

A sua faceta mais interessante, porém, é a das incontáveis usurpações e esbulhos patrimoniais que cometeu, fosse durante o período de anarquia vivido pelo reino durante o reinado de D. Sancho II, ou fosse graças às posições de destaque que ocupou durante os dois reinados seguintes. O certo é que conseguiu assenhorear-se de grande parte do património dos Bragançãos, como foi acima dito, detendo propriedades desde Chaves até Bragança. A título de exemplo, refiram-se os casos das freguesias de Santa Cruz e de Santa Comba da Vilariça: na primeira, obrigou o concelho a dar-lhe metade da vila do Prado que ele trazia ocupada à força, tendo também filhado o prado de Ribas; na segunda, filhou metade do lugar de Prados da Ribeira, e todo o lugar de Vilarelhos e os herdamentos de Carvelas e de Vale de Asnos ${ }^{86}$.

Com a morte de D. Nuno Martins de Chacim, em 1284, chega-se ao fim desta primeira etapa da análise da senhorialização das terras transmontanas situadas junto à margem direita do Douro, e confinantes com o reino de Leão. A sua morte, e a extinção, a breve trecho, da linhagem dos de Chacim, significa também o termo da história de uma linhagem que, como penso ter demonstrado, não se podia dissociar da evolução do próprio território. Os Bragançãos o integraram no reino de Portugal, e os mesmos Bragançãos, de certa forma, o foram moldando e às suas populações segundo os seus imensos poder e prestígio. Quando chegamos ao final do século XIII, porém, o poder era já do Rei que, agora, não se submetia a pedir consilium para conceder forais, mas antes ordenava vigorosas inquirições para pôr cobro aos desmandos e abusos senhoriais.

\section{O REPOVOAMENTO E A SENHORIALIZAÇÃo DA MARgEM ESQUERDA DO CôA ATÉ Ao TrATAdo de AlCANiCES (1297).}

O documento mais antigo que se conhece sobre esta região, datado de 960, refere que a condessa Dona Châmoa Rodrigues doou ao mosteiro de Guimarães um vasto conjunto de bens, entre os quais se incluíam os castelos de Caria, de Penedono, de Sernancelhe, de Trancoso, de Moreira de Rei, de Longroiva, de Alcarva, de Meda, de Numão e de Muxagata ${ }^{87}$. Poucos anos depois desta gran-

${ }_{86}$ PMH, Inq., pp. 1274-1275 e 1275-1275, respectivamente. Para uma visão global dos seus bens, v.g. VentURA, Leontina: A Nobreza ..., vol. II, quadros e mapa nos Anexos à Prosopografia.

87 Portugaliae Monumenta Historica, Diplomata et Chartae, vol. I, Lisboa, Academia Real das Sciencias, 1868-1873, doc. $\mathrm{n}^{\circ}$ LXXXI (PMH, DC). As referências a esta doação, como é de calcular, abundam na bibliografia. Por mais recente, cite-se o trabalho de BARROCA, Mário Jorge: Do castelo da reconquista ao castelo românico, Porto, 1990-1991, p. 94. Carece de fundamentação documental a 
de doação as investidas muçulmanas, conduzidas por Almançor, ocuparam todo o território situado a sul do rio Douro, perdendo-se então estes castelos. Com a subida ao trono de Fernando I de Leão e Castela, o Magno, a Reconquista retoma a sua dinâmica, e já num inventário de 1059 se verifica que o cenóbio Vimaranense estava de novo na posse de todos aqueles lugares. Sabe-se que a região a sul do Douro, compreendida entre os rios Távora e Águeda não integrou o território portucalense, pelo que todo o repovoamento dessa área deverá ter sido da responsabilidade de um presor leonês, existindo bons argumentos que levam a admitir que os Bragançãos tenham recebido o governo de todo o imenso território que «extremava» o lado oriental do Condado Portucalense, desde Chaves até Bragança, e daí para sul, ultrapassando o Douro entre aqueles dois rios, até ao Sabugal.

A confirmar estas hipóteses, de resto, está o facto de a recuperação e a posse de todos aqueles castelos e lugares por parte do Mosteiro de Guimarães não ter sido muito prolongada, uma vez que entrados no século XII —ou talvez mesmo desde $1072^{88}$ — parte deles já estarem na mão da referida estirpe dos Bragançãos.

Neste contexto, não posso deixar de voltar a referir um documento que citei no início do ponto anterior, para ilustrar o enorme poder, territorial e senhorial, detido pelos senhores de Bragança. Trata-se, como se recordarão, do foral outorgado em 1130 a Numão e seus termos, por D. Fernão Mendes de Bragança II. Esta carta foralenga, para além de ser o primeiro documento conhecido para a região do Côa — depois dos de 960 e de 1059, acima citados-é também um bom exemplo da forma como o seu povoamento foi promovido, pelo menos no início, pelo poder senhorial, isto é, a par, tal como já foi sublinhado, de um processo de senhorialização $0^{89}$.

Recorde-se, ainda, que o termo então concedido a Numão era muito vasto, chegando no seu limite Oriental até à margem esquerda do rio Águeda. A acção repovoadora de Fernão Mendes II, porém, não se confinou a Numão. Com efeito, parece que também se lhe ficou a dever o povoamento de Longroiva, à qual também terá concedido carta de foral, em data desconhecida mas anterior a 1145 , ano em que aquele magnate, juntamente com os seus filhos e a sua segunda mulher, a Infanta Dona Sancha, doou o castelo e a vila à Ordem do Templo ${ }^{90}$.

afirmação de que o castelo de Casteição também pertenceria à referida condessa, e que a mesma o teria doado em 960 juntamente com os outros castelos (GEPB, vol.XXXIX, p.282). Entretanto, em 1059, quando é feito um inventário dos bens do mosteiro de Guimarães, aqueles castelos voltam então a ser citados ( $P M H-D C$, doc. $\mathrm{n}^{\circ}$ CCCCXX).

${ }^{88}$ É possível que Fernão Mendes I tenha recebido essa tenência na mesma altura em que recebeu o governo de Chaves (vd. nota 11).

$89 \mathrm{Vd}$. nota 36.

90 A doação foi citada por Brandão, Frei Francisco: Monarquia Lusitana. Parte Quinta (Introdução por REGO, A. da Silva, Lisboa, Imprensa Nacional-Casa da Moeda, 1976³ fl.108 
Finalmente, em 1159, D. Afonso Henriques, em conjunto com o seu cunhado, Fernão Mendes II e a sua irmã, a Infanta Dona Sancha, concedeu foral a Trevões (concelho de S. João da Pesqueira) ${ }^{91}$. A acção povoadora dos Bragançãos a sul do Douro não terá ficado por aqui, uma vez que se afigura verosímil que o topónimo Vascoveiro (fg. do c. de Pinhel), se fique a dever a povoamento ou propriedade de D.Vasco Pires de Bragança, o Veirã $0^{92}$, neto daquele magnate, e que já aqui foi citado a propósito da sua presença na corte de D. Sancho I93.

Nestas circunstâncias, parece-me importante sublinhar que a acção povoadora encetada pelos senhores de Bragança terá incentivado o nosso primeiro monarca, tal como já devidamente o valorizou Paulo Dordio Gomes, a «iniciar uma nova fase de alargamento e consolidação do seu domínio para Este, sobre as comunidades do Alto Douro, concedendo, a partir dos meados da década de 1150, um grande número de forais: Freixo de Espada à Cinta (entre 1155 e 1157 [com o consentimento de Fernão Mendes II]), Trancoso, Marialva, Aguiar da Beira, Celorico da Beira e Moreira de Rei (entre 1157 e 1169), Trevões (1159 [de novo com aquele magnate]) e Mós (1162)»94.

Por outro lado, esta política régia de concessão de forais, iniciada por D. Afonso Henriques e vigorosamente mantida por D. Sancho I, e ainda um pouco continuada por D. Afonso $\mathrm{II}^{95}$, para além de fortalecer o povoamento e a defesa do território mais próximo da raia, acabava também por criar entraves ao alastramento do senhorialismo na região da Beira, promovendo o desenvolvimento de uma apertada malha concelhia, beneficiada por privilégios adequa-

(ML.V), e encontra-se integralmente transcrita em Viterbo, Joaquim de Santa Rosa de: Elucidário das Palavras, Termos e Frases que em Portugal antigamente se usaram e que hoje regularmente se ignoram (Ed. por Mário Fiúza), vol. II, Porto, Livraria Civilização, 1966, p. 587, nota 1. Há quem entenda que o povoamento de Longroiva se ficou a dever ao seu avô materno, D. Egas Gondesendes de Baião (GEPB, vol. XV, p. 415). A maioria dos autores, porém, parece inclinar-se para a autoria de Fernão Mendes, até porque, segundo creio, a área de influência dos de Baião nunca se terá estendido para limites tão orientais (sobre a concessão do foral e posterior doação aos freires Templários, onde o próprio doador afirma ter povoado Longroiva, entre Numão e Marialva e o Côa (cfr. AzEvedo, Rui Pinto de: «Fronteiras entre Portugal e Leão em Riba-Côa, antes do tratado de Alcanices (1297)», in Biblos, vol. X, n. ${ }^{\circ} 9-12$ (Set., Dez. 1934), p. 456, e IDEM, «Riba Côa ...», p. 259, nota 29; A. de Almeida Fernandes: Guimarães..., p. 78, nota 1; GOMES, Paulo Dordio: «O Povoamento...», p. 174). Segundo um autor anónimo - Almeida Fernandes? - é possível que também Muxagata tenha sido anexada nessa mesma doação (GEPB, vol. XVIII, p. 318).

${ }_{91}$ PMH, Inq., p. 1095.

92 GEPB, vol. XXXIV, p. 321.

$93 \mathrm{Vd}$. nota 64.

94 Gomes, Paulo Dordio, «O Povoamento ...,», pp. 172-173.

95 Para além dos forais referidos pelo autor agora citado, acrescentem-se ainda os conferidos por D. Afonso Henriques a Urros (1182), Trancoso, Moreira de Rei, Marialva e Celorico da Beira (1185), por D. Sancho I a Gouveia e Covilhã (1186), Bragança (1187), Valhelhas (1188), Pinhel (1191) e Penedono (1195), e por D. Afonso II a Sebadelhe (1220), cfr. PMH, Leges, pp. 424-426, 433-436, 436-439, 440-442, 442-447, 453-456, 456-459, 463-464, 466-471, 481-482, 498-500 e 583-584. 
dos a uma situação de guerra permanente, sobretudo ao nível da cavalaria vilã. Circunstâncias, portanto, que procuravam dissuadir a aproximação de novos senhores, especialmente para sul dos domínios dos Bragançãos, tendo a Coroa para com estes, desde o início, e recordando os exemplos referidos, um relacionamento que se pode dizer pautado pela «diplomacia».

Por outro lado, ainda, também se poderá acrescentar que, enquanto o poder concelhio foi vigoroso e, sobretudo, sustentado por um poder central organizado e seguro, tal como já se começa a pressentir com D. Sancho I, e se constata com veemência durante o reinado de D. Afonso II, não haveria grandes hipóteses para que a senhorialização alastrasse de uma forma desmesurada num território com estas características de organização social. Problema que, pelo contrário, ia ganhando no Entre Douro-e-Minho uma dimensão inquietadora para o poder régio, a justificar a realização, em 1220, das primeiras Inquiriçõos Gerais.

Não se deverá, assim, estranhar a absoluta ausência de informações sobre a presença da nobreza em terras de Riba-Côa, com excepção do que foi referido para os Bragançãos, até aos finais do século XII e inícios do século XIII. Nesta centúria, porém, e devido a circunstâncias de natureza política, a realidade iria alterar-se profundamente. De certa forma, acaba por ser sintomático que o último dado de que disponho para o século XII relativo a esta região seja sobre um confronto bélico.

Talvez por volta de 1198, desferiu-se um combate nas cercanias de Pinhel, mais concretamente em Ervas Tenras. Combate violento, sem dúvida, de tal forma que esse evento perdurou na memória dos homens como um verdadeiro marco de referência temporal. É o caso de algumas das testemunhas ouvidas aquando das Inquirições de 1258, que sessenta anos depois se referiam a um determinado acontecimento como sendo anterior ou coevo da de Pinhel96. Também as fontes linhagísticas nos deixaram a memória desse evento, pois que ele foi funesto para as linhagens que ali viram cair alguns dos seus filhos ${ }^{97}$.

Guerra de fronteira, pois que é de uma terra raiana que se trata, enfrentando-se aí portugueses contra leoneses. Avancemos, então, para o século XIII, quando estas terras também viram o sangue derramado entre irmãos e parentes.

A partir da morte de D. Sancho I, ocorrida em 1211, tem início um processo extremamente importante, com vastas repercussões políticas e sociais. $\mathrm{Na}$ verdade, o novo monarca, D. Afonso II, elege como política prioritária da sua governação a organização administrativa do Reino, só possível com um poder régio forte e centralizador — revelada como um "programa governativo» nas leis promulgadas nas Cortes de 1211 - tendo por isso que assumir uma postura determinada no sentido de controlar e reduzir os poderes senhoriais, quer laicos quer eclesiásticos.

96 Vários exemplos são citados por FernANDEs, A. de Almeida, Esparsos de História (Séculos XII e XIII), Porto, 1970, p.41.

97 «D. Gonçalo Velasques [de Barbosa], o que mataram na lide de Ervas Tenras $(L D 1 \mathrm{M} 3)$; «E D. Vermu[do] Soares [de Riba Douro], (...), matarom-no na lide d'Ervas Tenras» (LD10Q2). 
Desde logo recusando o cumprimento de algumas das disposições testamentárias de seu pai, que cumulavam de benesses as Infantas suas irmãs, D.Afonso II abriu declaradamente as hostilidades, sobretudo contra a alta nobreza. São bem conhecidas as consequências dessa atitude régia: o exílio dos seus dois irmãos, os Infantes D. Fernando e D. Pedro Sanches, como mais tarde seguiria o mesmo caminho o bastardo régio Martim Sanches, o exílio do mordomo-mor de seu pai, D. Gonçalo Mendes, chefe da todo-poderosa linhagem dos Sousas ${ }^{98}$, e, naturalmente, a revolta de suas irmãs.

Este ambiente de tensão política, que chegou mesmo a provocar a invasão de Portugal pelas forças de Afonso IX de Leão, acabou também por provocar graves conflitos sociais, como a divisão de uma parte da nobreza entre uma facção régia e uma outra nobiliárquica. Ambiente que se prolongou, como é sabido, após a morte de D. Afonso II, acabando por transformar o reinado de seu filho D. Sancho II, num período de forte instabilidade social e política, que viria a degenerar numa verdadeira anarquia que atingiu o seu auge na Guerra Civil de 1245 , com a posterior deposição e exílio do monarca, e a sua substituição pelo seu irmão, D. Afonso III, rei a partir de 1248 .

De uma maneira geral, portanto, pode afirmar-se que a primeira metade do século XIII, e mais especialmente o segundo quartel da centúria, coincidindo com o período do reinado de D. Sancho II (1223-1248), foi o palco privilegiado para uma considerável expansão do regime senhorial, devido à debilidade do poder régio, com um aumento acentuado dos abusos e usurpações senhoriais. Detectados em todo o Reino, sobretudo, como seria de esperar, nas áreas que tradicionalmente se caracterizavam por aquele regime, como o Entre Douro-eMinho, mas que se tornam bastante visíveis em áreas onde ele tinha sido de alguma forma controlado até essa altura, como é o caso da região que temos vindo a analisar. Desta forma, não se deverá estranhar um maior número de informações sobre a presença de nobres neste território, e que noticiam, na maior parte das vezes, situações de abuso, de violência ou de irregularidade ${ }^{99}$.

${ }_{98}$ Entendo que, tal como já referi, os exílios dos membros da linhagem dos Bragançãos presentes na Corte, Fernão Fernandes, a partir de 1204, e os seus tios Garcia e Vasco Pires a partir de 1206, deverão ser considerados como o resultado da rivalidade existente entre as duas poderosas linhagens, mas poderão também ser considerados como fruto de um eventual apoio dado por aqueles ao Infante herdeiro.

99 Deve-se advertir o leitor para o facto de estes desmandos terem continuado, porventura de uma forma menos alargada, para além do reinado de D. Sancho II, como se pode comprovar pela leitura das Inquirições promulgadas por D. Afonso III e por D. Dinis, as fontes mais privilegiadas para o conhecimento da propriedade e actuação da nobreza durante o século XIII e parte do século XIV. Contudo, deve-se ter em conta que esses textos, sobretudo as Inquirições de 1258, ao acentuarem, de uma forma quase sistemática, que os abusos registados datavam do reinado de D.Sancho II, também acabavam por servir fins de propaganda política, isto é, procuravam, dessa forma, legitimar a deposição daquele monarca e a sua substituição pelo seu irmão, D. Afonso III, o rei que, através de medidas reguladoras, como as mesmas Inquirições, procurava pacificar e organizar o Reino. Para se perceber a dimensão de algumas destas usurpações, veja-se o seguinte 
O primeiro exemplo que vou referir, é talvez dos mais elucidativos para melhor se compreender a mutação social e política ocorrida no Reino, em consequência do clima de forte instabilidade e da debilidade do poder régio. $\mathrm{O}$ caso passou-se entre 1238 e 1242, sendo tenente de Lamego D. Abril Pires de Lumiares. Neto de D. Afonso Henriques e do seu célebre Aio, D. Egas Moniz, era então o mais próximo representante dos de Riba Douro ${ }^{100}$, e o verdadeiro «senhor» da Beira por estes anos, com a acumulação de várias tenências, como terei a oportunidade de comentar no próximo ponto. Por volta de 1238, dizia, D. Abril Pires quis obter o estatuto de vizinho de Numão para, dessa forma, aí poder obter propriedades; temendo-se o concelho do seu grande poder e da sua violência, "concedeu-lhe uma vasta herdade "entre Cedovim, Longroiva e Muxagata» «101. Contudo, e por que isso o não satisfizesse, exigiu ainda o lugar de Touça e, perante a negativa do concelho feriu três homens e matou um outro, tal como nos relata o texto das Inquirições de $1288-90^{102}$, do que resultou que o concelho de Numão acabasse por ceder, doando-lhe o dito lugar em 1242, e recebendo-o por vizinho esperando dele receber protecção ${ }^{103}$.

Tendo morrido pouco tempo depois (1245), tinha deixado aquele lugar ao mosteiro de Tarouca, doação que viria a ser confirmada alguns anos depois por D. Pero Anes de Riba de Vizela (1269) ${ }^{104}$, seu neto-materno, e que ainda terei ocasião de referir de novo.

exemplo, tirado das Inquirições de 1288-90, e relativo ao então julgado de Moreira de Rei, hoje freguesia do concelho de Trancoso: na aldeia de Terrenho, no termo de Moreira, Soeiro Pacheco tinha adquirido dois casais a um foreiro; depois, juntamente com outros fidalgos, foi-os acrescentando de tal forma que a área usurpada, também durante o reinado de D. Sancho II, chegava aos 50 casais (ANTT Leitura Nova, Inquirições da Beira e d'Além Douro, fl. 2v $\mathrm{v}^{\circ}$ ).

100 A linhagem de Riba Douro foi, a par da dos Bragançãos, uma das principais responsáveis pela senhorialização do território situado na margem esquerda do rio Douro, neste caso no seu curso médio. Muito poderosos e com um património bastante extenso, sobretudo acrescentado com as generosas dádivas do nosso primeiro monarca a favor de D. Egas Moniz, não chegaram, no tempo deste, a atingir a área que agora se analisa, muito embora a honra de Caria ultrapassasse o Távora (cfr. Fernandes, A. de Almeida: Guimarães..., pp.117 e 144). A chegada dos Riba Douro fez-se, assim, por acção de Abril Pires [de Riba Douro], senhor do couto de Lumiares.

${ }_{101}$ GEPB, vol. XIX, p.17.

102 ANTT, Leitura Nova, Inquirições da Beira e d'Além Douro, fl. $2 \mathrm{v}^{\mathrm{o}}$.

${ }^{103}$ Livro das Doaçôes de Tarouca (ed. por A. de Almeida Fernandes), in Taraucae Monumenta Historica, vol. I/1, Documenta (Leitura, Sumários e Notas de ...), Braga, Câmara Municipal de Tarouca, 1991, p. 529 (doc. 622). De resto, D. Abril Pires era, perdoe-se-me a expressão, um verdadeiro "profissional» na extorsão de terras aos concelhos, sob a capa da protecção: assim, no vizinho concelho de Penedono, também as Inquiriz̧ões de 1288-90 referem que a aldeia de Póvoa tinha sido povoada por aquele magnate no tempo de D. Sancho II, num herdamento que o concelho lhe tinha «dado», e aonde ele fez uma honra, então na posse da viúva de seu neto, Dona Urraca Afonso (ANTT, Leitura Nova, Inquirições da Beira e d'Além Douro, fl.1v $\mathrm{v}^{\mathrm{O}}$ ).

104 GEPB, vol. XXXII, p. 325. Sobre a posse de Touça pelo mosteiro de Tarouca, cfr. A. de Almeida FERNANDES: Acção dos Cistercienses de Tarouca (As granjas nos sécs. XII e XIII), Guimarães, 1974, pp. 279-282. 
Sobre esta última linhagem, e ainda no actual concelho de Vila Nova de Foz Côa, conhece-se uma outra notícia, também curiosa, mas agora a propósito da freguesia de Almendra. Como se sabe, o território situado entre a margem direita do Côa, onde aquela freguesia se encontra, e a margem esquerda do Águeda só foi definitivamente integrado em Portugal com o Tratado de Alcanices, em 1297. O certo é, porém, que em 1270 esta freguesia estava na posse de um português, D. Gil Martins de Riba de Vizela, tio do Pero Anes acima referido. Dá-se o caso que este nobre e poderoso fidalgo, rico-homem da corte de D. Sancho II e depois de D. Afonso III, incompatibilizou-se com este último monarca, de quem chegou a ser mordomo-mor entre 1253 e 1264, exilando-se na corte de Castela, para onde foi naquele último ano acompanhado pelo filho, D. Martim Gil de Riba de Vizela I, e onde viria a falecer em 1274105. Em 1270, assim exilado, recebeu do rei Afonso X, o Sábio, uma doação que englobava Almendra e todo o seu termo ${ }^{106}$, então ainda sob o domínio castelhano. $\mathrm{Na}$ mão dos de Riba de Vizela se manteve ${ }^{107}$ — muito embora tenha sido objecto de conflito entre a linhagem e o concelho de Castelo Rodrigo- até à morte do seu último representante, D. Martim Gil II, $2^{\circ}$ Conde de Barcelos e neto de D. Gil Martins ${ }^{108}$.

Situação algo semelhante, mas agora para o actual concelho de Figueira de Castelo Rodrigo, é a de Gonçalo Martins Machado, a quem o concelho de Castelo Rodrigo confirma, em 1281, a venda que ele fizera ao mosteiro de Santa Maria de Aguiar da terça parte da granja da Fonte dos Cantos, na freguesia de Freixeda do Torrão ${ }^{109}$.

${ }_{105}$ Para a biografia deste indivíduo, v.g Ventura, Leontina: A Nobreza,,,, vol. II, pp. 690-697.

106 Tanto quanto sei, a doação foi referida pela primeira vez na $M L . V$, fl. $240 \mathrm{v}^{\circ}$.

107 Depois de Alcanices, D. Dinis confirmou (1298) a posse de Almendra a D. Martim Gil II $\left(M L . V\right.$, fl. $\left.240 \mathrm{v}^{\circ}\right)$. Sobre este processo, v.g. NogueIRA, José Artur Anes Duarte, «A Organização Municipal da Extremadura Leonesa nos Séculos XII e XIII», in Boletim da Faculdade de Direito de Coimbra, vol. LVIII, tomo II (1982), pp. 423-426.

${ }_{108}$ Muito embora diga respeito a uma zona fora da área em estudo, se bem que próxima, parece-me importante uma outra referência relativa a D. Gil Martins, sobre um acordo por ele feito, também já exilado, com a Ordem de Alcântara. Corria o ano de 1267, e D. Gil Martins celebrou um acordo com o Mestre daquela Ordem militar a favor do seu filho, D. Martim Gil I, também exilado, como já disse: a Ordem doava-lhe, a título de préstamo vitalício por 1.000 morabitinos, a bailia de Valhelhas (c. Guarda), com todas as suas pertenças, excepto a igreja e as dízimas, incluindo o castelo com seus termos, sementeiras feitas de 30 moios, gado, aves domésticas, móveis, utensílios de lavoura, etc.; o acordo foi confirmado por Martim Gil em 1274, por ocasião da morte de seu pai (cfr. PizArRo, José Augusto de Sotto Mayor: Linhagens..., vol. I, pp. 547, nota 63, e 558, nota 80). AzEVEDO, Rui Pinto de: «Fronteiras ...», p. 462, in nota, também cita estes documentos, para além de outros que referem doações relativas a Valhelhas feitas por D. João I: a primeira, ainda como Mestre de Avis, sobre as rendas da comenda a favor de João Gomes da Silva (1384); no ano seguinte, já como monarca, da terra de Valhelhas a favor de Álvaro Gil Cabral, alcaide da Guarda; e, em 1386, agora a favor do exilado castelhano Fernão Álvares Queirós.

109 Documento publicado por AzEvedo, Pedro de: «Dois documentos de Riba-Côa da época leonesa», in Revista de História, vol. II (1913), pp.185-186. Não estou totalmente certo de que fosse 
Passando agora para o concelho da Meda, de novo se vão encontrar os senhores de Riba Douro. Primeiro, por uma doação régia de 1211, onde se refere D. Lourenço Soares de Riba Douro, neto do Aio, como senhor ou tenente de Marialva, sendo então um tal Paio Mendes o seu alcaide ${ }^{110}$; depois, por Dona Urraca Abril de Lumiares, filha de D. Abril Pires, que, tal como seu pai, também beneficiou o mosteiro de Tarouca com os bens que possuía em Longroiva, doação mais tarde confirmada por D. Dinis ${ }^{111}$. Por fim, uma última referência, também para Marialva, agora a propósito de uma nova linhagem, a dos Gatos, ramo secundário da nossa já conhecida linhagem de Baião e que teve uma expressiva implantação patrimonial na Beira ${ }^{112}$. Segundo as Inquirições de 128890, a quintã de Pousada, no termo de Marialva, tinha sido de um clérigo que a doara à Sé de Lamego, mas trazia-a então emprazada da dita Sé Afonso Lopes Gato, que aí fizera uma honra, deixando por isso de pagar foros ao Rei, que por sentença a deitou em devasso ${ }^{113}$.

Quanto a Pinhel, as informações são mais abundantes, e introduzem novas linhagens na região. A primeira linhagem que tenho que referir, a dos Sousas, era também a primeira do Reino. Todo-poderosa desde a fundação e durante os dois primeiros reinados fora a que mais acusara a política centralizadora promovida por D. Afonso II. Retirados da corte ou exilados, a ela regressam já no final daquele reinado ou no início do de D. Sancho II que, então ainda menor, fica inteiramente na mão dos poderosos Sousãos, uma das linhagens que depois mais viria a contribuir para a sua deposição e a sua substituição por D. Afonso III ${ }^{114}$. Factos de todos conhecidos, e que explicam a sua presença, como ricos-homens, à frente das principais terras beirãs durante o reinado do Capelo. Por esta época, era chefe da linhagem D. Gonçalo Mendes de Sousa II, que fora mordomo-mor de D. Sancho I, entre 1192 e 1211, e que depois deteve várias tenências nesta região, entre as quais a de Pinhel, à frente da se encontrava em $1223^{115}$.

Terá sido nestas circunstâncias, segundo me parece, que D. Gonçalo Mendes usurpou a vila e o termo de Pomares (fg. do c. de Pinhel), que depois honrou e transmitiu a seu sobrinho, D. Gonçalo Garcia de Sousa ${ }^{116}$, genro de

português, muito embora o nome e patronímico sejam comuns, nessa época, a esta família; é, contudo, a única informação que conheço, anterior ao século XIV, para Figueira de Castelo Rodrigo, muito embora ainda sob jurisdição castelhana.

110 Brandẽo, Frei António: Monarquia Lusitana. Parte Quarta (Introdução de A. da Silva Rego), Lisboa, Imprensa Nacional, Casa da Moeda, $1974^{3}$, fl. $60 \mathrm{v}^{\circ}$ (a partir de agora citada como ML.IV).

${ }^{111} G E P B$, vol. XV, p. 415.

112 Sobre a linhagem dos Gatos, v.g. José PIZARro, Augusto de Sotto Mayor: Linhagens..., vol. I, pp. 387-402.

113 ANTT, Leitura Nova, Inquirições da Beira e d'Além Douro, fl. 2vº.

114 Sobre a importância desta linhagem, v.g. MATTOSo, José: Identificação..., vol. I, pp.156160, Ventura, Leontina, 1992, vol. II, pp. 705-722, e PiZARro, José Augusto de Sotto Mayor: Linhagens ..., vol. I, pp. 205-225.

115 No ponto seguinte terei ocasião de precisar todas estas indicações.

116 GEPB, vol. XXII, p. 328. 
D. Afonso III, alferes-mor deste rei e de seu filho, e último senhor da linhagem. Também o irmão deste último, D. Mem Garcia de Sousa, na qualidade de tenente de Trancoso, se apoderou de Bouça Cova e de Vila Franca das Naves, no termo de Trancoso, que depois a sua viúva, Dona Teresa Anes de Lima, doou ao mosteiro de Salzedas em $1267^{117}$.

Descendo agora um pouco na hierarquia nobiliárquica, vamos encontrar uma nova linhagem, os Ervilhões, ou melhor, de Ervilhão, não muito conhecida para além dos livros de linhagens medievais, e que detinham o couto de Ervilhão, situado na fg. de Souro Pires do c. de Pinhel. A linhagem era nortenha, dos Mogudos de Sendim, mas aproximaram-se da Beira durante o século XIII, detectando as Inquirições de 1258 bens de Pero Martins Ervilhão em Celorico da Beira, o provável fundador do couto ${ }^{118}$. Ainda ao nível da nobreza regional média, ou inferior, se encontravam também os de Amaral e os de Vaiões, nestes dois casos linhagens de origem beirã, que deixaram ao mosteiro de Salzedas vários bens situados em Pinhel ou no seu termo, nas décadas de 40 e de 60 de Duzentos ${ }^{119}$. Finalmente, e no que já se vai tornando um hábito, vamos de novo encontrar os de Riba de Vizela. Desta vez, porém, não se trata de um caso de usurpação senhorial, mas antes de uma posse inteiramente legítima, e contando mesmo com o beneplácito régio. Assim, por doação de D. Afonso III de 1265, a título de dote pelo seu casamento com Urraca Afonso, filha bastarda do monarca, D. Pero Anes recebe metade da aldeia de Lamegal e metade do padroado da igreja desse lugar, no termo de Pinhel ${ }^{120}$; termo esse onde também se situava a aldeia de Espedrada, na fg. de Freixedas, e que D. Pero Anes detinha por herança paterna ${ }^{121}$.

Passando para o concelho de Almeida, uma breve paragem para, de novo, se referirem os de Riba de Vizela, tratando-se, desta vez, de alguns herdamentos, casas e vinhas, sitos nas freguesias de Ade, de Castelo Bom e de Castelo Mendo, e que pertenceram a D. Gil Martins, como bens de património paterno ${ }^{122}$.

Chegamos, por fim, ao concelho de Sabugal, extrema meridional do território estudado, e onde se vão encontrar alguns exemplos interessantes de senhorialização. É o caso da fg. de Águas Belas, lugar do então concelho de Sor-

117 GEPB, vol. XXXIX, pp. 99-100. Vila Franca é fg. do c. de Trancoso, e vizinha da de Bouça Cova, do c. de Pinhel, pelo que D. Mem Garcia, como tenente de Trancoso, terá feito a anexação da segunda à primeira.

118 GEPB, vol. XXIX, pp. 748-749. Pero Martins é referido em LL27A3, 30B4, e 46A3 e B4.

119 VASCONCELlos, J. Leite de: Livro da Fundação do Mosteiro de Salzedas por Fr. Baltazar dos Reis. Manuscrito do século XVII, publicado (agora pela primeira vez) como apenso às Memórias de Mondim da Beira de ..., Lisboa, Imprensa Nacional, 1934, pp.120-121 (também cit. in GEPB, vol. XXXIX, p. 749).

120 Ref. na ML.IV, fl. 221, e por Ventura, Leontina: $A$ Nobreza..., vol. II, p. 704. A doação também era recordada pelos inquiridos de 1288-90 (ANTT, Leitura Nova, Inquirições da Beira e d'Além Douro, fl. 3).

${ }^{121}$ Cfr. Ventura, Leontina: A Nobreza..., vol. II, Anexos à Prosopografia, Quadro dos «Bens de Pero Anes Gago [de Riba de Vizela]».

122 Ventura, Leontina: A Nobreza..., vol. II, p. 692, e Anexos à Prosopografia, Quadro dos «Bens de Gil Martins de Riba de Vizela». 
telha, concelho esse que, no tempo de D. Sancho II, cedeu a D. Ponço Afonso de Baião, já aqui referido e que na altura era tenente da Beira e de Trasserra, um herdamento onde lavrassem 6 juntas de bois num dia; mas, a partir daí foio alargando, acabando por povoar e honrar o dito lugar, retirando-o à jurisdição de Sortelha. A honra assim criada, passou depois para sua filha, Dona Estevaínha, e depois para o filho desta, o rico-homem D. Lourenço Soares de Valadares, sendo tudo devassado por ocasião das Inquirições de 1288-90123. Mais bens aqui terá tido D. Ponço Afonso, porque esta mesma fonte refere que o seu genro, D. Soeiro Pais de Valadares, tinha honrado o lugar (fg.) da Moita, bem como o seu neto, o já referido D. Lourenço Soares, que por 6 casais tinha honrado todo o lugar de Lamosa ${ }^{124}$.

Também em Sabugal se encontravam os Riba de Vizela, não só aqueles que viviam no Reino, como acabou de se referir na última nota, mas também os que viviam fora dele. Era o caso de Dona Teresa Gil de Riba de Vizela, filha do já nosso conhecido D. Gil Martins, que deverá ter acompanhado no exílio para Castela - acabando mesmo por se tornar amante do rei Sancho IV (LL16G6) — e onde recebeu, entre outros numerosos bens e privilégios, os direitos reais e senhoriais do Sabugal ${ }^{125}$.

As Inquiriçôes de 1288-90 revelam outros bens desta importante linhagem, mas agora em relação a um dos seus ramos secundários, o dos senhores de Melo. Exemplo bem conhecido da implantação senhorial na região da Serra da Estrela, graças à constituição do importante senhorio e honra de Melo (c. de Gouveia), não será de admirar que também este ramo apareça na região do Côa, considerando a forte implantação ali por parte da linhagem-mãe. Assim, aquelas fontes referem que a aldeia do Amial, no julgado de Sortelha, foi ganha e honrada por D. Mem Soares de Melo no tempo de D. Afonso III ${ }^{126}$, de quem efectivamente foi um dos mais fiéis vassalos ${ }^{127}$.

Da região do Sabugal chega-nos ainda uma outra notícia interessante, agora como palco de uma guerra. No Livro de Linhagens do Conde D. Pedro, en contrase a seguinte notícia: «E o sobredito Fernam Soarez e Sentil Soarez, irmãos de Paai Soarez, moordomo do ifante dom Afonso, morrerom na lide d'Alfaiates, quando lidou dom Alvar Nuniz de Lara com os concelhos de toda a terra, sendo elles vassalos de dom Alvaro» (LL65L5).

${ }^{123}$ ANTT, Leitura Nova, Inquirições da Beira e d'Além Douro, fls.3vo-4 (este caso é cit. na GEPB, vol. XXIX, pp. 703-704 e vol. XXXVII, pp. 720-721).

${ }_{124}$ ANTT, Leitura Nova, Inquirições da Beira e d'Além Douro, fl.4. Desconheço a origem da informação relativa a Sortelha, segundo a qual esta teria sido doada pelo rei a D. João Pires de Aboim onde também deteve alguns bens D. Pero Anes de Riba de Vizela (cfr. GEPB.XXIX.703).

125 Cfr. PiZARro, José Augusto de Sotto Mayor: Linhagens (...), vol. I, pp. 548-549.

126 ANTT, Leitura Nova, Inquirições da Beira e d'Além Douro, fl. 4 (ref. na GEPB, vol. XXVI, p. 505 e vol. XXIX, p.704, e cit. por PiZARro, José Augusto de Sotto Mayor: Linhagens (...), vol. I, p. 568).

127 Sobre este indivíduo, cfr. Ventura, Leontina: A Nobreza..., vol. II, pp. 667-669; sobre a linhagem dos Melos, cfr. PIZARro, José Augusto de Sotto Mayor: Linhagens..., vol. I, pp. 565-575. 
Esta lide de Alfaiates, ocorrida em $1286^{128}$, não foi tanto, como se poderia depreender, entre portugueses e castelhanos, mas sim o transportar de uma questão interna castelhana para o território fronteiriço da Riba Côa. D. Álvaro Nunes de Lara era um dos mais poderosos senhores castelhanos, que por desavenças com Sancho IV se refugiou em Portugal, fazendo, a partir daqui, ataques aos concelhos do outro lado da fronteira, no que parece ter sido apoiado pelo Infante D. Afonso de Portalegre, irmão de D. Dinis. A participação do Infante português nestes sucessos não será de estranhar, tendo em conta a sua permanente rebeldia em relação ao irmão, aproveitando o posicionamento fronteiriço dos seus vastos senhorios para mover constantes ataques à autoridade régia. De resto, a referência explícita ao facto de os dois irmãos falecidos no combate serem irmãos de Paio Soares de Barbudo, mordomo de D. Afonso, só vem confirmar as ligações entre D. Álvaro de Lara e o Infante português. Esta situação só veria o seu termo com a intervenção armada dos dois monarcas ${ }^{129}$, mas ainda faria mais vítimas do lado dos vassalos portugueses daquele senhor castelhano, como foi o caso de Nuno Rodrigues Bocarro, já aqui referido ${ }^{130}$.

Guerras que, a breve trecho, de novo despontariam na região, mas agora verdadeiramente entre Portugal e Castela. Não vale a pena aqui repetir os seus meandros. O seu resultado, porém, e que todos conhecemos, resultou, com o Tratado de Alcanices de 1297, que lhe pôs termo, na integração de todo o território para lá do Côa no espaço nacional. Assim constituído, Portugal apresentaria até aos dias de hoje, salvo a perda de Olivença, a mesma expressão territorial, o que faz do seu contorno a linha de fronteira mais estável e antiga do Mundo.

Antes de concluir, porém, ainda gostaria de fazer uma última apreciação do processo de senhorialização, desde a origem até Alcanices, tomando agora como referência o elenco dos ricos-homens que foram governando estes domínios fronteiriços ao longo do tempo. Creio bem, e alguns exemplos que ficaram referidos o comprovam, que os tenentes destas terras foram também veículos importantes para o alastrar daquele fenómeno. Constatação óbvia, parece-me, para o caso transmontano, mas que merece a pena verificar para o conjunto do espaço.

\section{As TenênCias Fronteiriças de Trás-os-Montes e da Beira (SÉCU- LOS XII-XIII).}

A questão das tenências está desde há muito estudada, desde o seu significado político até à sua importância para o evoluir do poder das linhagens mais poderosas, passando pela análise da sua transmissão ${ }^{131}$. Assim sendo, não faria

\footnotetext{
${ }^{128} M L . V$, fls. $121 \mathrm{v}^{\mathrm{o}}-123$.

$129 M L . V$, fls. $125 \mathrm{v}^{\circ}$ e $128 \mathrm{v}^{\circ}-131 \mathrm{v}^{\circ}$.

$130 \mathrm{Vd}$. nota 75.

${ }^{131}$ Mattoso, José: Ricos-Homens..., pp.131-1452, e Ventura, Leontina, A Nobreza..., vol.I, pp. 61-287.
} 
sentido repeti-lo aqui. $\mathrm{O}$ que agora se pretende é verificar até que ponto existe uma coincidência entre as famílias dos tenentes e as que surgiram na documentação como protagonistas de actos de senhorialização ${ }^{132}$.

Começarei pela tenência de Bragança. Durante mais de um século, isto é, desde 1128 até 1232, o governo deste território é detido pelos Bragançãos - a Fernão Mendes II (1128-1145), segue-se o seu filho Pero Fernandes (11651187), e depois o seu bisneto Fernão Fernandes (1192-1204 e 1218-1232), tendo em conta que o intervalo em que decorre o exílio deste último é preenchido por Ponço Afonso de Baião (1211-1217), genro de Pero Fernandes. E, se depois da morte de Fernão Fernandes a tenência é ocupada por Vasco Mendes de Sousa (1233-1236), logo a seguir volta a surgir um Braganção, Fernão Garcia (1237-1238), neto de Pero Fernandes. Esta sucessão revela com clareza a íntima ligação do território à linhagem a que, como se viu, se ficara a dever em boa parte a sua integração no espaço nacional. Não espanta, por isso, que a linhagem tenha surgido associada a vários casos, por um lado, de povoamento e, por outro, de abuso e usurpação senhorial. A presença dos Sousas é esporádica, e decorre sobretudo do período conturbado em que ela se verifica, não se devendo esquecer que também Fernão Fernandes fora rico-homem de Panóias (1218 e 1226-1229), área tradicionalmente dos Sousãos.

Depois do afastamento dos Bragançãos a tenência é disputada, salvo duas excepções, entre os Teles de Albuquerque - Martim Afonso (1243 e 1258-1262) e Afonso Teles (1256-1257) —e os Baiões_ Afonso Lopes (1248-1253) e Fernão Lopes (1253-1256). Estes últimos, como já referi, estavam ligados aos Bragançãos, uma vez que eram ambos bisnetos de D. Pero Fernandes, enquanto os primeiros, aparentados com o monarca por serem filhos de uma bastarda de D. Sancho I, representavam uma poderosa linhagem castelhana patrimonialmente localizada junto à fronteira portuguesa, pelo que se compreende a vontade de D. Afonso III em os atrair à sua fidelidade, tanto mais que o irmão mais velho de ambos, João Afonso Telo I, foi o primeiro alferes-mor do monarca. O ciclo fecha-se de novo com os Bragançãos, uma vez que o último tenente, Nuno Martins de Chacim (1265-1284), descendia também daqueles senhores e foi, como se viu, um dos principais agentes da senhorialização abusiva da região brigantina.

Passemos o Douro, e centremo-nos agora nas tenências beirãs ${ }^{133}$, começan-

132 Para o fazer vou-me socorrer das listagens de tenentes recentemente elaboradas por Leontina Ventura para todo o Reino - para cujo excelente trabalho desde já remeto o leitor-, mas das quais só aproveitarei as relativas ao território aqui estudado (vd. VENTURA, Leontina: $A$ Nobreza..., vol. II, pp. 997-1038).

133 Para não alongar este texto, que se pretende o mais sintético possível, não irei referir algumas tenências que seguramente tinham influência até à fronteira, como é o caso das de Lamego e de Viseu. Fique, no entanto, a ideia, de que existe uma forte presença em ambas dos senhores de Riba Douro, que mais à frente veremos representados por Abril Pires de Lumiares, figura cuja actuação já ficou suficientemente retractada nas páginas anteriores. Por outro lado, algumas tenências menores, mas bem próximas do «nosso» território, como sejam as da Covilhã, de Gouveia 
do pela própria tenência da Beira, isto é, o território situado a Norte da cordilheira central. O primeiro governador conhecido é Lourenço Soares de Riba Douro (1211-1221), o que se entende bem tendo em conta a preponderância desta linhagem na região, como veremos em casos posteriores. Por sua morte, e extinção da linha principal da linhagem, o cargo será dividido entre os Baiões e os Riba de Vizela ${ }^{134}$, não sendo necessário recordar ao leitor os variados casos de senhorialização, ainda há pouco referidos, protagonizados por indivíduos daquelas duas poderosas linhagens. Vejamos, por fim, uma série de tenências com um território mais reduzido, mas directamente ligadas aos espaços que tenho vindo a analisar.

Assim, em Numão, encontra-se Afonso Lopes de Baião em 1247, Martim Gil de Riba de Vizela I entre 1257 e 1260, e, por fim, Estêvão Anes de Sousa em 1265. Enquanto que para Pinhel, sucedem-se Lourenço Soares de Riba Douro (1213), Gonçalo Mendes de Sousa II (1223), Rodrigo Sanches (1227), Abril Pires de Lumiares (1233-1243), João Garcia de Sousa (1248-1253), e finalmente Pero Ponces de Baião (1254). Creio bem que não valerá a pena fazer qualquer comentário, seguramente redundante, de tal forma fica patente a quase constância das linhagens que sucessivamente se ligam ao território beirão, ou seja, praticamente as mesmas que protagonizaram os casos mais eloquentes da senhorialização deste espaço.

Seja-me permitido, no entanto, e antes de concluir, deixar devidamente valorizada a presença na região dos senhores de Riba Douro durante o reinado de D. Sancho II, referindo o conjunto de tenências que foram detidas por aquele que, nesse período, representava a linhagem: D. Abril Pires de [Riba Douro] Lumiares foi tenente da Guarda (1229-1241), Lamego (1222-1232/1239-1244), Marialva (1229), Pinhel (1233-1243), Riba de Paiva (1241), Tarouca (1229), Trancoso (1226/1229-1245) e Viseu (1222-1229/1238-1243). Creio que, assim, ficam devidamente esclarecidas as razões que levaram alguns concelhos da Beira a temerem tanto o seu poder, e a aceitarem as suas pretensões de se tornar seu vizinho.

\section{CONCLUSÕES}

Esta análise partiu de um tempo muito recuado, quando o esforço de $R e-$ conquista começou a dar os primeiros passos verdadeiramente decisivos. A par

\footnotetext{
ou de Trancoso, deixam bem patente a influência dos Riba Douro, dos Baiões e dos Riba de Vizela, o que vem confirmar o quadro que gradualmente se vai delineando.

134 A sequência é a seguinte: Ponço Afonso de Baião (1222-1235), João Garcia de Sousa (12471251), Diogo Lopes de Baião (1253), Pero Ponces de Baião (1254), Martim Gil de Riba de Vizela (1255-1264) e Pero Anes de Riba de Vizela (1268-1283). A intromissão dos Sousas, se assim me posso exprimir, não será de estranhar: em primeiro lugar pela preponderância de João Garcia e dos seus irmãos durante o reinado de D. Afonso III; em segundo lugar, porque por morte de Lourenço Soares, o seu cunhado Gonçalo Mendes de Sousa II, tio de João, deteve várias das tenências tradicionalmente governadas pelos senhores de Riba Douro, como a de Lamego ou a de Viseu.
} 
deste esforço de conquista territorial, os diferentes monarcas procuraram também lançar as raízes incipientes de uma administração que permitisse um mínimo de condições favoráveis à fixação de novas ou de antigas populações. Com recursos limitados, viram-se na necessidade de partilhar o seu poder, ou melhor, de o delegar nas mãos de indivíduos da sua confiança e de reconhecido valor guerreiro, os condes, para o auxiliarem naquelas tarefas que lhe eram de todo impossível controlar directamente.

Fruto das conjunturas militares e políticas, ou de momentos em que a instabilidade se introduzia no círculo do poder régio, aqueles senhores também foram delegando aqueles mesmos poderes nas mãos de alguns dos seus próprios vassalos, pelo que a autoridade pública foi sendo gradualmente usurpada por uma cadeia de mãos hierarquicamente ligadas entre si, do que resultou o enfraquecimento da potestas régia. Foi o tempo do arranque do processo de senhorialização do espaço.

Quando se atingiu o final do século XI, já o Norte do território que viria a chamar-se Portugal se encontrava, em grande medida, controlado por uma densa teia de senhorios laicos e eclesiásticos, no meio da qual iam sobrevivendo comunidades rurais e pastoris, ainda livres, mas que a todo o momento iam sofrendo os propósitos usurpadores senhoriais. Para lá da serra do Marão e do rio Távora, separados, ou melhor, mediados pelo alcantilado Douro, senhoreavam diferentes linhagens originariamente ligadas ao reino de Leão. Uma delas se destacava pelo enorme espaço onde exerciam a sua autoridade, pública e privada: os Bragançãos.

Foi através da sua história e evolução que fomos acompanhando o lento processo de inserção daquele espaço no território português, bem como a sua respectiva organização social: aqueles senhores, antes de mais, e praticamente hegemónicos no médio e alto vales do rio Douro quase até aos finais do século XIII, e depois, a Sul, várias linhagens da alta e média nobreza de corte, aqui ou ali ombreando com outras famílias de menor prestígio e poder, geralmente autóctones, e comunidades livres que eram protegidas e incentivadas pela Coroa através de cartas de foral.

Em 1287 o rei D. Dinis extinguiu as tenências, num gesto repleto de intencionalidade política, e que fez parte de um conjunto mais alargado de medidas tendentes a controlar o poder nobiliárquico. Se o monarca pretendia sobretudo atingir a alta nobreza, retirando-lhe o último símbolo mais claramente feudal do poder que durante séculos exercera, não é menos verdade que também abolia, pese embora o facto de as tenências não serem já senão meramente honoríficas, um dos mecanismos que mais tinham favorecido a senhorialização do Norte do Reino ${ }^{135}$.

Isto significa que os séculos XIV e XV assistiram ao fim da senhorialização deste espaço, ou que o processo continuou em moldes diferentes? A esta como a outras questões se procurará responder na segunda parte deste trabalho.

135 Uma síntese sobre a política de controlo senhorial deste monarca encontra-se em José Augusto de Sotto Mayor PizArro, D. Dinis: Lisboa, Círculo de Leitores, 2005. 